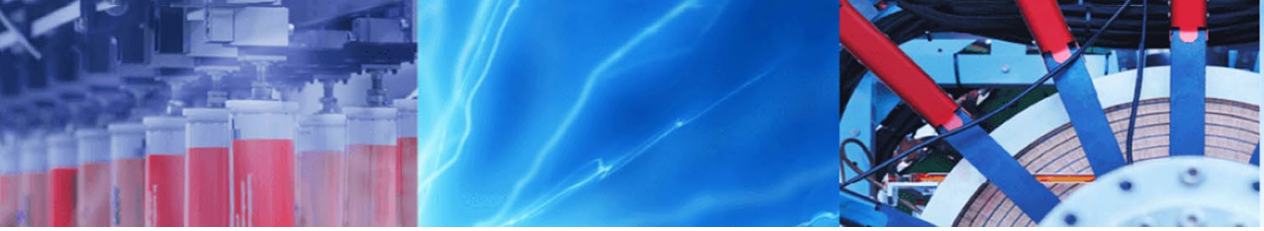

Research Article

\title{
Groundwater quality assessment using multivariate statistical technique and hydro-chemical facies in Birbhum District, West Bengal, India
}

\author{
Niladri Das ${ }^{1} \cdot$ Prolay Mondal $^{2} \cdot$ Ranajit Ghosh $^{3} \cdot$ Subhasish Sutradhar ${ }^{2}$
}

(c) Springer Nature Switzerland AG 2019

\begin{abstract}
The assessment of quality of groundwater is an important issue in the present era of population growth, massive agricultural development, industrialization and urbanization. As the demand of groundwater increases, the quality becomes deteriorated. In this background, the study of groundwater quality in Birbhum District is very much important as this area has been characterized by diversified rock formations. For the analysis purpose, 14 parameters regarding the hydro-chemical data of groundwater, viz. $\mathrm{P}^{\mathrm{H}}$, electrical conductivity, total hardness, calcium, magnesium, sodium, potassium, bicarbonate, chloride, sulfate, fluoride, silicon dioxide, phosphate and iron, were selected. The present study has been carried out using multivariate statistical method, viz. principle component analysis (PCA) and cluster analysis. In addition, different hydro-chemical facies in terms of hydro-chemical diagrams have been used to show the present status of groundwater quality in the concerned area. The result of PCA, a multivariate statistical technique, reveals that it extracts five major factors accounting for $80 \%$ of the total variance. Fluoride has been extracted as first factor. It is because the western part of the district has been characterized by highly fluoride contaminated area where basaltic terrain is present. The study also shows concentration of cation and anion that are present in the order of $\mathrm{Na}^{+}>\mathrm{Ca}^{2+}>\mathrm{Mg}^{2+}>\mathrm{K}^{+}=\mathrm{Cl}^{-}>\mathrm{HCO}^{3-}>\mathrm{SO}_{4}{ }^{2-}$. Two clusters have been prepared: one for sample villages and another for chemical components. Sample village-wise cluster reveals that Baidyanath, Muluk, Khayrasole, Md Bazaar, Patel Nagar, etc. bear same chemical characteristics, while chemical component cluster shows the homogeneous grouping among $\mathrm{P}^{\mathrm{H}}, \mathrm{PO}_{4}, \mathrm{SiO}_{2}$, Fe. Diagrammatic presentation of chemical parameters is also an important aspect in this study. Here application of Wilcox diagram basically depicts the nature of water for the suitability of irrigation. It shows that about $50 \%$ samples out of total sample have been characterized by excellent to good, the rest $25 \%$ samples present in good to permissible category, $20 \%$ are under the category of permissible to doubtful and $5 \%$ belong to the category of doubtful to unsuitable, while Gibbs mechanism displays $68 \%$ samples belonging to the category of rock dominance and the rest $32 \%$ in precipitation dominance category. This kind of study obviously demand an important space as groundwater quality is directly related to human health. So, for the sustainable development of human health, this type of study opens a new dimension for the betterment of the society and the concerned region.
\end{abstract}

Keywords Groundwater quality · Multivariate statistical analysis $\cdot$ Hydro-chemical facies

$\triangle$ Niladri Das, niladridas123@gmail.com; Prolay Mondal, monprolay@gmail.com; Ranajit Ghosh, www.ranajitghosh@gmail.com; Subhasish Sutradhar, subhasish2396@gmail.com | 'Department of Geography, Hiralal Bhakat College, Nalhati, Birbhum, West Bengal 731220, India. ${ }^{2}$ Department of Geography, Raiganj University, Raiganj, Uttar Dinajpur 733134, India. ${ }^{3}$ Department of Geography, Suri Vidyasagar College, Suri, Birbhum, West Bengal 731101, India.

SN Applied Sciences (2019) 1:825 | https://doi.org/10.1007/s42452-019-0841-5

Received: 12 April 2019 / Accepted: 26 June 2019 / Published online: 4 July 2019 


\section{Introduction}

Groundwater is an indispensable element for human life and welfare $[58,65]$. It meets the essential needs in different economic sectors and daily life, viz. the agricultural, industrial and household requirements $[8,90,99,103]$. Among all the physio-chemical aspects of groundwater, the quality of it is a very important matter of concern because the sustainable development of groundwater in various fields depends on the availability of good quality of groundwater [66, 80, 83, 91, 94]. In this connection, the assessment of hydro-chemical properties of groundwater is one of the prime tasks in the present-day context [21]. Surface water is normally affected by surface pollutants. But groundwater is highly affected by existing geology, degree of chemical weathering, quality of recharge, level of groundwater, some surface element sources, etc. [54]. So, the quality of groundwater is subjected to the interaction between geological and hydrological processes $[1,11$, $12,25,33,51,60,88,93,102]$.

With the rapid increase in population, economic demand increases in parallel day by day, leading to industrial and agricultural growth. Consumption of chemical fertilizers and pesticides to enhance more agricultural production has become very common practice. All of these result in the deterioration of water quality. Moreover, large-scale drafting of groundwater for economic and domestic purposes accelerates the depletion rate of groundwater level [20]. This depletion of groundwater table and collapse of water quality is the emerging problem in most of the towns and cities of the country $[7,22,24,30,37-40,42-46,48,53,64,69,73,82,98]$. The chemical properties of groundwater have been severely affected by geological structure and human harmful activities. Degradation of groundwater cannot be recovered. For example, the fluoride contents in groundwater provides safeguard against dental curiosity specifically for children [54]. If the fluoride concentration is more than $15 \mathrm{mg} / \mathrm{L}$, it leads to the chance of tooth decay and dental fluorosis occurs due to higher concentration $[106,107]$. The admissible level of fluoride for drinking water according to World Health Organization is $15 \mathrm{mg} / \mathrm{L}$ [113]. If the nitrate concentration is above $45 \mathrm{mg} / \mathrm{L}$, this leads to the risk of methemoglobinemia which usually affects infants [41]. Large accumulation of sulfates causes diarrhea [54]. According to Azizullah et al. [9], high concentration of Fe in groundwater generates some serious diseases like cancer, diabetes, liver- and heart-related problems, etc. The presence of high percentage of arsenic in drinking water leads to the occurrence of skin diseases [17].

Human health largely depends on the quality of groundwater $[74,115]$. Therefore, in recent times one of the major thrusts in research is to analyze the hydrochemical properties of groundwater, and now, it has become a firm part of regional hydro-chemical studies [104].

For the analysis of groundwater hydro-chemistry, various quantitative techniques have been successfully applied. For example, correlation matrix is an important statistical technique to study relation between various hydro-geochemical data. It helps to identify the association between the groundwater chemical elements [61, 62 , $95,109,112]$. Another important approach to explain the groundwater quality is the multivariate statistical analysis; principal component analysis or PCA is one of these $[75,78]$. It is basically applied to reduce the complication of several input variables and extracts the major components from a large volume of data set $[27,29,62,76]$. Factor analysis (FA), as a technique of PCA, possibly helps to transform correlated sets of variables known as principal components (PCs) $[92,110]$. Moreover, if multivariate treatment is successfully applied for the interpretation of environmental data, it will help to manage environmental system in better ways [23].

Four blocks of Birbhum District, namely Muraroi II, Nolhati II, Rampurhut II and Nanor, have been defined as semi-critical stage because of fluctuation of water level during pre- and post-monsoon stages of groundwater development [16]. Except this, fluoride contamination was first identified in the northwestern part of the Birbhum District. Iron is another mineralogical composition present in the groundwater and certain amount of iron is required for the human health [68], though iron may be harmful if its level is above $03 \mathrm{mg} / \mathrm{l}$ (milligrams per liter) [13].

For the assessment of groundwater quality, multivariate approach is widely accepted as quantitative technique in modern era $[2,28,77]$. Among various multivariate statistical methods, principal component analysis (PCA) and cluster analysis (CA) are able to extract the relationship between various variables and clearly explain the relation between them $[18,59,113]$. Therefore, PCA has been applied in this work to extract the major chemical components for determining the groundwater quality in the district. Cluster analysis which is the graphical presentation of chemical variables and which depicts the grouping of two or more variables based on the similarity of the chemical components with respect to the special characteristics has also been used here. It also helps in the proper interpretation of groundwater chemistry in a hydro-geochemical context $[52,77,117]$.

The main purpose of the study is to identify the hydrochemical characteristics of groundwater from different wells of Birbhum District and to develop authentic statistical methods for assessing groundwater quality in spatial 


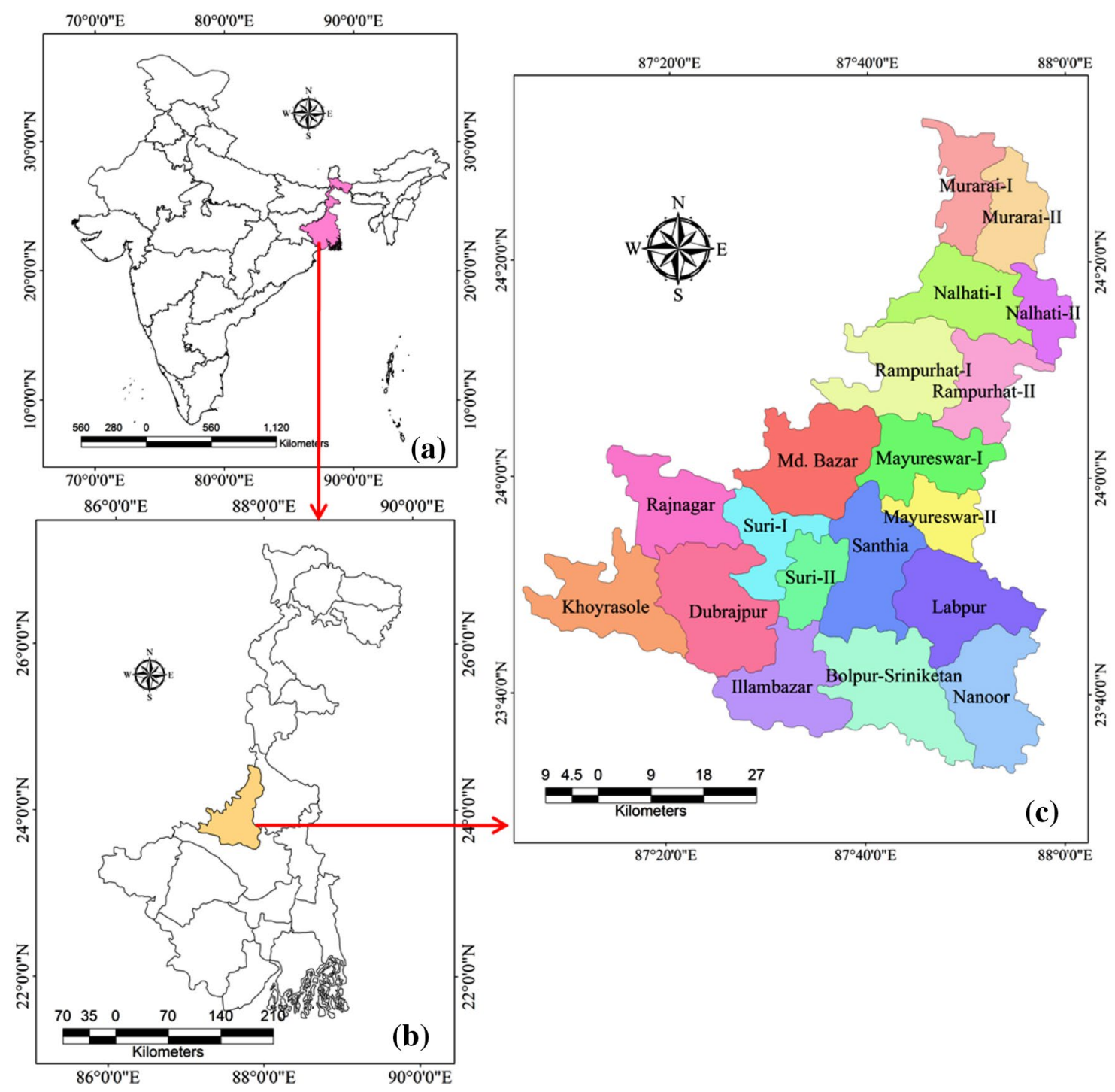

Fig. 1 Location map of a India, b West Bengal and c Birbhum District

context. Besides, the use of multivariate statistics to identify the major factors of controlling groundwater quality is not the prime objective of this study, but the analysis and presentation of those factors help to identify the major mineral concentration zones, not only the general minerals but also harmful minerals like fluoride, iron, etc. So, in the present-day context of environmental pollution, this kind of study is utmost relevant.

Except the multivariate statistical techniques, various other indices regarding the parameters of groundwater quality have been studied here like Gibbs ratio, permeability index (PI), percentage of sodium (\%Na), etc. [97]. Along with these indices, various graphical presentations have also been provided. Those are Wilcox diagram to show suitability of groundwater for irrigation, Doneen's chart to show permeability index and Gibbs diagrams to represent the mechanism of controlling the chemistry of groundwater.

\section{Materials and methods}

\subsection{Geographical description of the study area}

Spatially, Birbhum District is located between $23^{\circ} 32^{\prime}$ $30^{\prime \prime} \mathrm{N}-24^{\circ} 35^{\prime} 00^{\prime \prime} \mathrm{N}$ latitude and $87^{\circ} 05^{\prime} 04^{\prime \prime} \mathrm{E}-88^{\circ} 01^{\prime} 04^{\prime \prime} \mathrm{E}$, covering an area of $4545 \mathrm{sq} \mathrm{km}$, and it consists of $19 \mathrm{com}$ munity development (CD) blocks (Fig. 1) Administratively, this district is bounded by the Jharkhand state in the west and the north and Murshidabad in the east and Burdwan District in the south. 


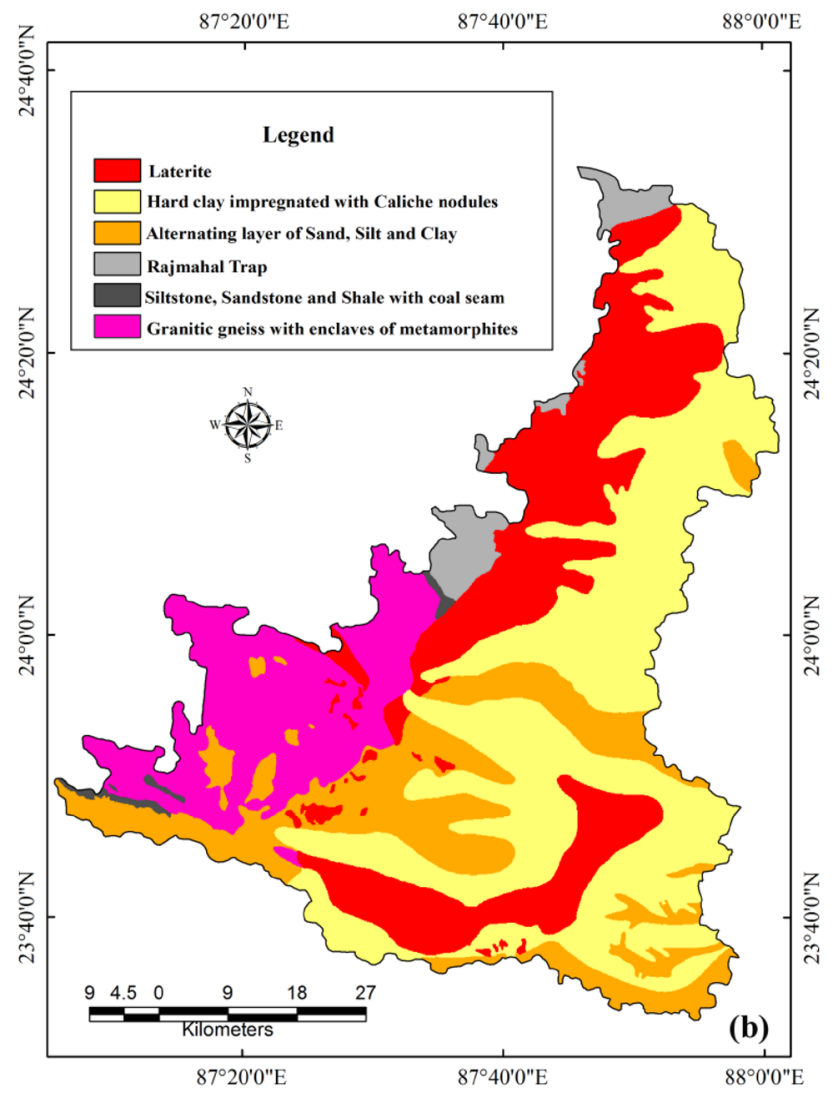

Fig. 2 Geological units of Birbhum District

Geographically, this region is under "Rarhbanga" area; the soil and landscape are very much similar to that of Murshidabad, Burdwan, Bankura and Midnapore. Geologically, this district comprises many rock formations. For example, dissected plateau composed of granitic gneiss of Archean age is present in the western portion of the district. Eastern part of the district has been formed by sediments of Gondwana period and also formed by laterite and the alluvium deposit (Fig. 2). The geological succession found in the study area is given in Table 1.

As we see, Birbhum District is a geologically diversified area, where Archaeans are the oldest rock formation, its granitoid and schistose rocks having crystallized at least 900 m.y. ago. These are a continuation to the east of the Peninsular Archaeans of the Chota Nagpur plateau. During upper Gondwana period, the Gondwana land was subjected to marked vulcanicity, which manifested itself into outpouring of Rajmahal lava flows and intrusion of numerous sills and dykes of basic and ultrabasic rocks. The geology of the eastern portion of the district, lie concealed below a capping of Holocene alluvium, was completely unknown until recently, till extensive subsurface investigations were carried out.

A large number of rivers run from west where plateau fringe is present to east with a little bit southeasterly inclination in the Suri subdivision and in the northeasterly inclination in the eastern half of the Rampurhat subdivision [20]. Both the Mayurakshi and Ajoy river valleys are of considerable size when they enter into the district. The river widths vary according to the configuration of the country, from 200 yards to half a mile [63] Expect Mayurakshi and the Ajoy, Kopai, Brahmhani, Dwarka and Bansloi are the main river systems of this district. The position of the major rivers is shown in Fig. 3

This district usually experiences a tropical monsoon climate where the summer temperature hike above $40^{\circ} \mathrm{C}$ and winter temperature falls around $10^{\circ} \mathrm{C}$ The average annual rainfall is about $14,305 \mathrm{~mm}$ [20].

\subsection{Data sets used}

For the analysis of hydro-chemical characteristics of the groundwater, fourteen parameters have been taken into consideration; namely, $\mathrm{P}^{\mathrm{H}}$, electrical conductivity $(\mathrm{EC})$, total hardness $(\mathrm{TH})$, calcium $(\mathrm{Ca})$, magnesium $(\mathrm{Mg})$, sodium $(\mathrm{Na})$, potassium $(\mathrm{K})$, bicarbonate $\left(\mathrm{HCO}_{3}\right)$, chloride $(\mathrm{Cl})$, sulfate

Table 1 Geological framework of Birbhum District

\begin{tabular}{ll}
\hline Era \\
$\begin{array}{l}\text { Recent } \\
\text { Middle to upper Jurassic }\end{array}$
\end{tabular}




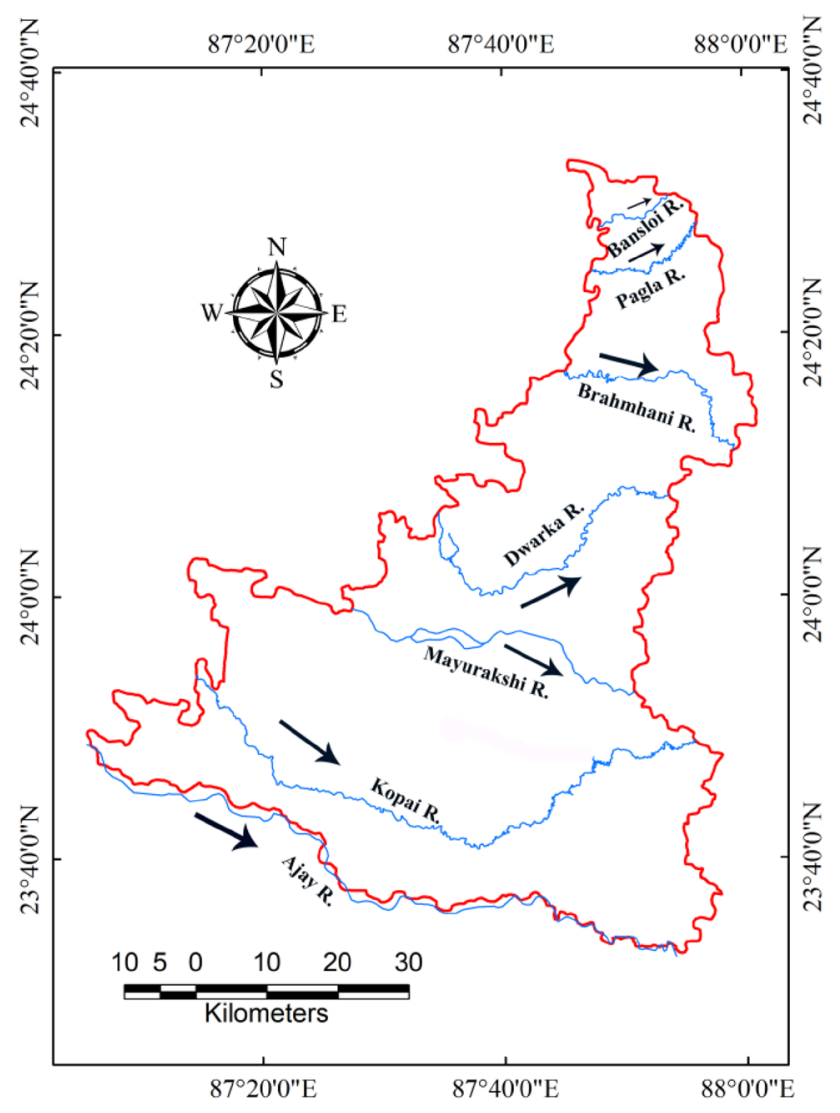

Fig. 3 Major river networks

$\left(\mathrm{SO}_{4}\right)$, fluoride $(\mathrm{F})$, silicon dioxide $\left(\mathrm{SiO}_{2}\right)$, phosphate $\left(\mathrm{PO}_{4}\right)$ and iron ( $\mathrm{Fe}$ ) have been collected from the Groundwater year book of West Bengal Andaman Nicobar Islands, published by Central Groundwater Board, Government of India, in 2015-2016. The data were collected by CGWB during pre-monsoon season from 108 bore wells, which are randomly present throughout the district.

\section{Method}

For the proper hydro-chemical analysis of groundwater data, principal component analysis (PCA) has been applied to reduce the dimensionality $[4,32,104]$. PCA has been calculated by using IBM SPSS statistical software version 25. Correlation matrix of Karl Pearson has been prepared to present the association between individual parameters of groundwater chemical and to identify the link between them $[5,112]$. The correlation value of $>05$ represents very high correlation between variables, $<05$ demarcated poor correlation between variables and 05 value of correlation represents moderate relationship between variables [108]. PCA provides the most powerful information about the components of a large data set with minimum loss of information [35]. In this study, for the proper interpretation of PCA varimax rotation has been used According to Guttman-Kaiser rule, only those factors which have the eigenvalue greater than 1 have been taken as major factors [14]. Therefore, for the proper extraction of the groundwater quality parameter eigenvalue is taken as $>1$ in IBM SPSS software. The graphical presentation of eigenvalue in respect of factors is called Cattle's (1966) scree Test [15]. It is a simple line segment plot that shows the fraction of total variance. It has been shown that when there are substantive factors, the slope of the line will be steep, but when the factors correspond to the error, the slope will be flat.

PCA can be expressed with the help of Eq. 1

$Z_{1}=a_{1} \times x_{1}+a_{2} \times x_{2}+\cdots+a_{14} \times x_{14}$

where $Z_{1}$ is the first principal component, $x_{1}, x_{2}, \ldots, x_{14}$ are the original variables (e.g., $\mathrm{P}^{\mathrm{H}}, \mathrm{EC}, \mathrm{Ca}, \mathrm{Mg}, \mathrm{Na}$, etc.) and $a_{1}$, $a_{2}, \ldots a_{14}$ are the coefficient or weight of each variable for the first principal component $Z_{1}$ (Vide Table 5).

From the result of the PCA, we have considered five PCs, i.e., $Z_{1}, Z_{2}, Z_{3}, Z_{4}$ and $Z_{5}$. Let $n$ be the number of observations of each of $x_{1}, x_{2}, \ldots, x_{14}$. Then $Z_{1}, Z_{2} \ldots Z_{14}$ will also have $n$ observation corresponding to $n$ observations of $x_{1}, x_{2}, \ldots, x_{14}$. To get the coefficient of PCs, we need to find eigenvalues and eigenvector of correlation matrix of the variable $x_{1}, x_{2}, \ldots, x_{14}$. This procedure has been run here with the help of IBM SPSS version 25 software.

Hierarchical cluster analysis or HCA is another method that has been applied here to classify homogeneous chemical groups as well as sample station-wise homogeneous groups. The most common theme of this method is joining the most similar observations in the data set [31]. Q-mode hierarchical cluster which has been accepted and used by several authors is applied here [36, 55, 57, 79]. The main aim of this method is to group more than one variables into a cluster. The Euclidean distance has been implied here to identify the similarities or differences between two sites I and $\mathrm{j}$ which has been calculated by using Eq. 2

$\left.d_{i j}^{2}=\sum_{(k=1)}^{m}\left(Z_{(i, k)}-Z_{(j, k)}\right)\right)$

where $d_{i j}$ is the Euclidean distance, $Z_{i k}$ and $Z_{j k}$ are the variable $k$ for objects $i$ and $j$, respectively, and $m$ is the number of variables.

The graphical presentation of cluster has been represented by dendrogram, which has been obtained from the Euclidean distance, and Ward's method has been used.

The spatial analysis of 14 groundwater chemical parameters has been carried out using the ArcGIS version 105 software. Interpolation of the data has been done using 
inverse distance-weighed (IDW) method of spatial analysis tool. Now the question is: Why 14 parameters have been selected to carry out this research? The 14 parameters have been considered by the standard parameters to identify the quality of the groundwater by CGWB [16]. Moreover, these 14 parameters are the ideal parameters for the reorganization of the suitability of the groundwater for irrigation or drinking purposes, so to calculate standard water quality index or WQI, the above-mentioned 14 parameters are very important for the water quality analyzers.

Various hydro-chemical facies like Wilcox diagram, Doneen's chart, USSL diagram and Gibbs diagrams have been plotted using AquaChem version 2011.1 software.

\section{Results and discussion}

\subsection{Spatial pattern of groundwater chemical}

Spatial pattern means the distribution of groundwater chemical in different parts of the study area. In all figures of the spatial pattern of groundwater chemical, it can be observed that there are numerous small pockets of chemical concentration, which look like stars. In this connection, it has been explained that interpolation method has been carried out to present spatiality, so on the basis of random data, this kind of spatially has been shown. Interpolation has been carried out in ArcGIS 10.5 software with the help of IDW tool, which was previously discussed in method section. In this section, distribution of all chemical components as well as their causes of formations has been analyzed.

The value of $\mathrm{P}^{\mathrm{H}}$ varies between 75 and 8 , which represents that the water is almost neutral in nature. $\mathrm{P}^{\mathrm{H}}$ value ranging from neutral to acidic is mainly associated with granitic formation $[31,47]$. Therefore, neutral to acidic $\mathrm{P}^{\mathrm{H}}$ can be observed in the southwestern side of the study area where granitic gneiss formation is predominant (Figs. 2, 3a). Lower $\mathrm{P}^{\mathrm{H}}$ value is the characteristic feature of large quantity of soluble salts, i.e., higher $\mathrm{EC}$ and high concentration of acidic ions such as $\mathrm{SO}_{4}^{-}$[71]. Figure $3 a, b$ and $j$ shows that the southern and southwestern parts of the district are characterized by lower $\mathrm{P}^{\mathrm{H}}$ value because of the presence of highly soluble salts and $\mathrm{SO}_{4}{ }^{-}$acidic ions.

Conductivity or the electrical conductivity is frequently used as the parameter to measure salinity in the water [87]. According to the State Water Resources Control Board, the drinking water standard for salinity is $900 \mu \mathrm{S} /$ $\mathrm{cm}$ (recommended) and the higher value of EC is $1600 \mu \mathrm{S} /$ $\mathrm{cm}$, although the value as higher as $2000 \mu \mathrm{S} / \mathrm{cm}$ may be acceptable for irrigation water [96]. According to Rhoades et al. [85], water can be classified into six groups
Table 2 Groups of EC concentration

\begin{tabular}{lll}
\hline Type & EC value in $\mu \mathrm{S} / \mathrm{cm}$ & Types of water \\
\hline I & EC $<700$ & Non-saline \\
II & 700 and 2000 & Slightly saline \\
III & 700 and 2000 & Moderately saline \\
IV & $>2000$ and $<10,000$ & Highly saline \\
V & 10,000 to 25,000 & Very highly saline \\
VI & 25,000 to 45,000 & Brine water \\
\hline
\end{tabular}

based on the concentration of EC [86] which is shown in Table 2.

Figures 2 and $4 \mathrm{~b}$ reveal the fact that electrical conductivity is related to the laterite geological structure. The electrical conductivity in the lateritic geological structure increases when the degree of saturation increases [10]. Therefore, the lateritic patch of western and southwestern parts of the Birbhum District has been characterized by high electrical conductivity concentration. The rest of the study area is about non-saline to slightly saline zone.

The primary cause of the presence of total hardness is the concentration of cations mainly calcium and magnesium which are dissolved in the water and anions like carbonate, bicarbonate, chloride and sulfate [21, 23].

Figure $5 \mathrm{a}-\mathrm{c}$ reveals the fact that there is a strong positive relationship between total hardness and other cations and anions. The $r^{2}$ value of the relationship ranges from 06 to 09 which clearly describes that total hardness is strongly determined by calcium, magnesium and chloride. The map (Fig. 4c-e, i) strongly displays the relationship between total hardness and other cations and anions. It can be found that high concentration $\mathrm{TH}$ is present in the northwestern and southwestern parts of the district where calcium, magnesium and chloride are also highly concentrated.

Calcium bicarbonate ion is highly determined in the southern part of the district (Fig. 4h). This mainly forms due to the reaction of carbon dioxide with water and carbonate rocks like limestone and dolomite [3]. In Birbhum District, $\mathrm{HCO}_{3}$ concentrated in hard clay impregnated with caliche nodules geological deposit. So, it is very common to find $\mathrm{HCO}_{3}$ in this geological structure.

Initially, sulfate ion has no harmful effect on living organism. It basically influences salinity [21]. WHO-recommended maximum allowance limit of sulfate is $400 \mathrm{mg} / \mathrm{l}$. In this region, sulfate ion varies from 001 to $264 \mathrm{mg} / \mathrm{l}$. So, this area has been characterized by optimum amount of sulfate.

Fluoride is a very important hydro-chemical trace element in groundwater. High concentration of fluoride ion may cause fluorosis-related health disorders. The groundwater of the area is characterized by semiarid condition, 

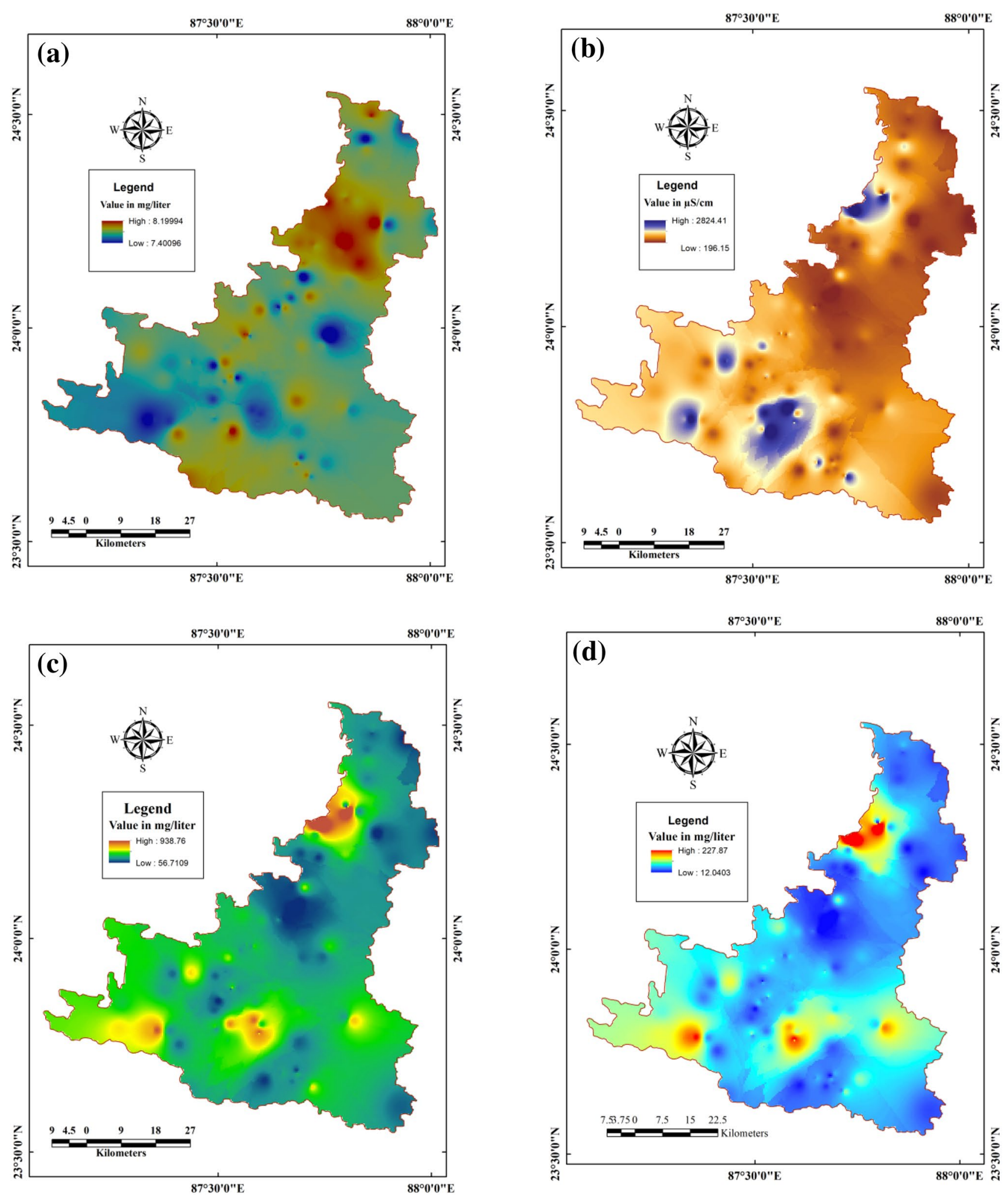

Fig. 4 a $\mathrm{P}^{\mathrm{H}}$, b electrical conductivity, $\mathbf{c}$ total hardness, $\mathbf{d}$ calcium, e magnesium, $\mathbf{f}$ sodium, $\mathbf{g}$ potassium, $\mathbf{h}$ calcium bicarbonate, $\mathbf{i}$ chloride, $\mathbf{j}$ sulfate, $\mathbf{k}$ fluoride, I phosphate, $\mathbf{m}$ silicon dioxide, $\mathbf{n}$ iron 

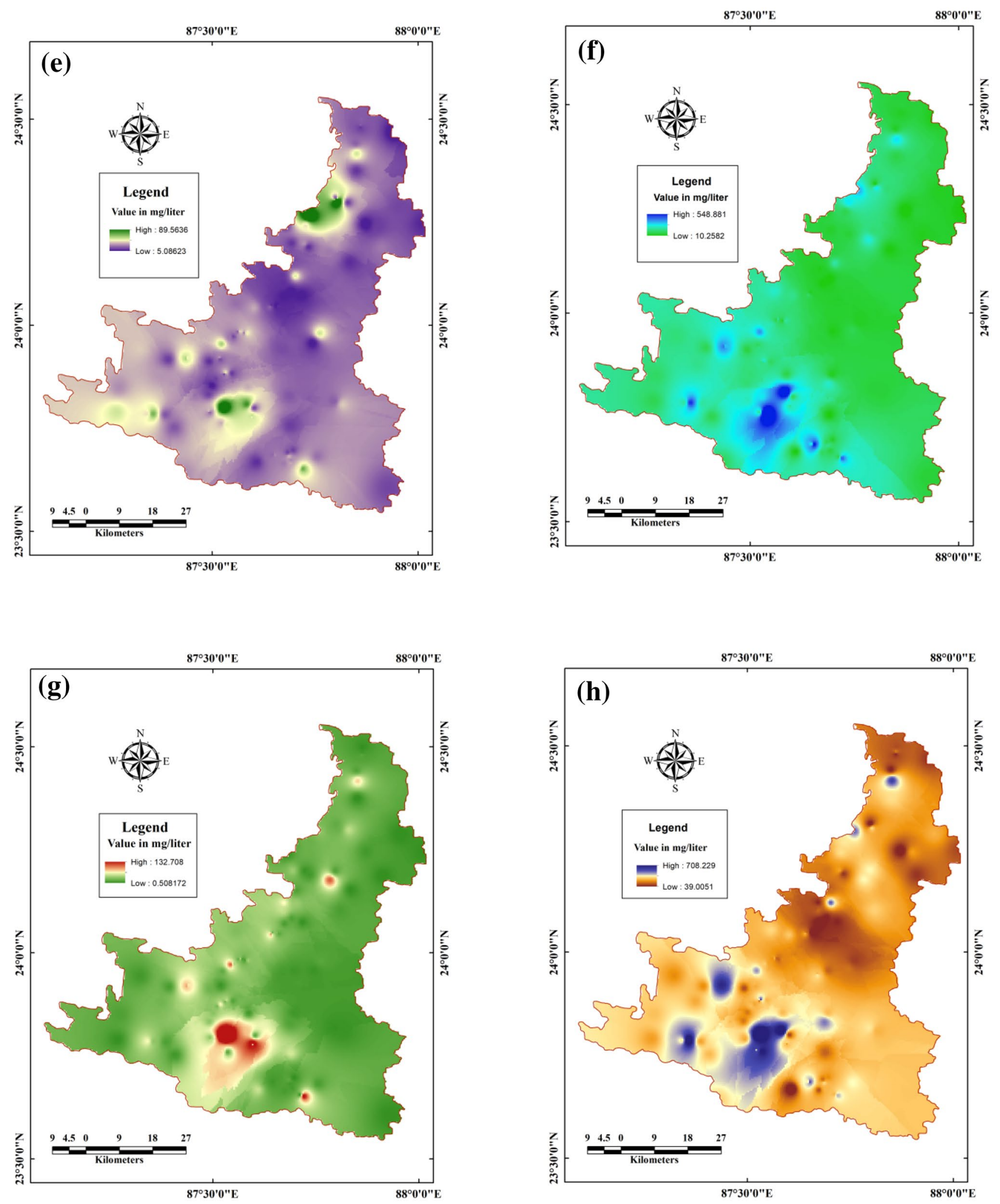

Fig. 4 (continued) 

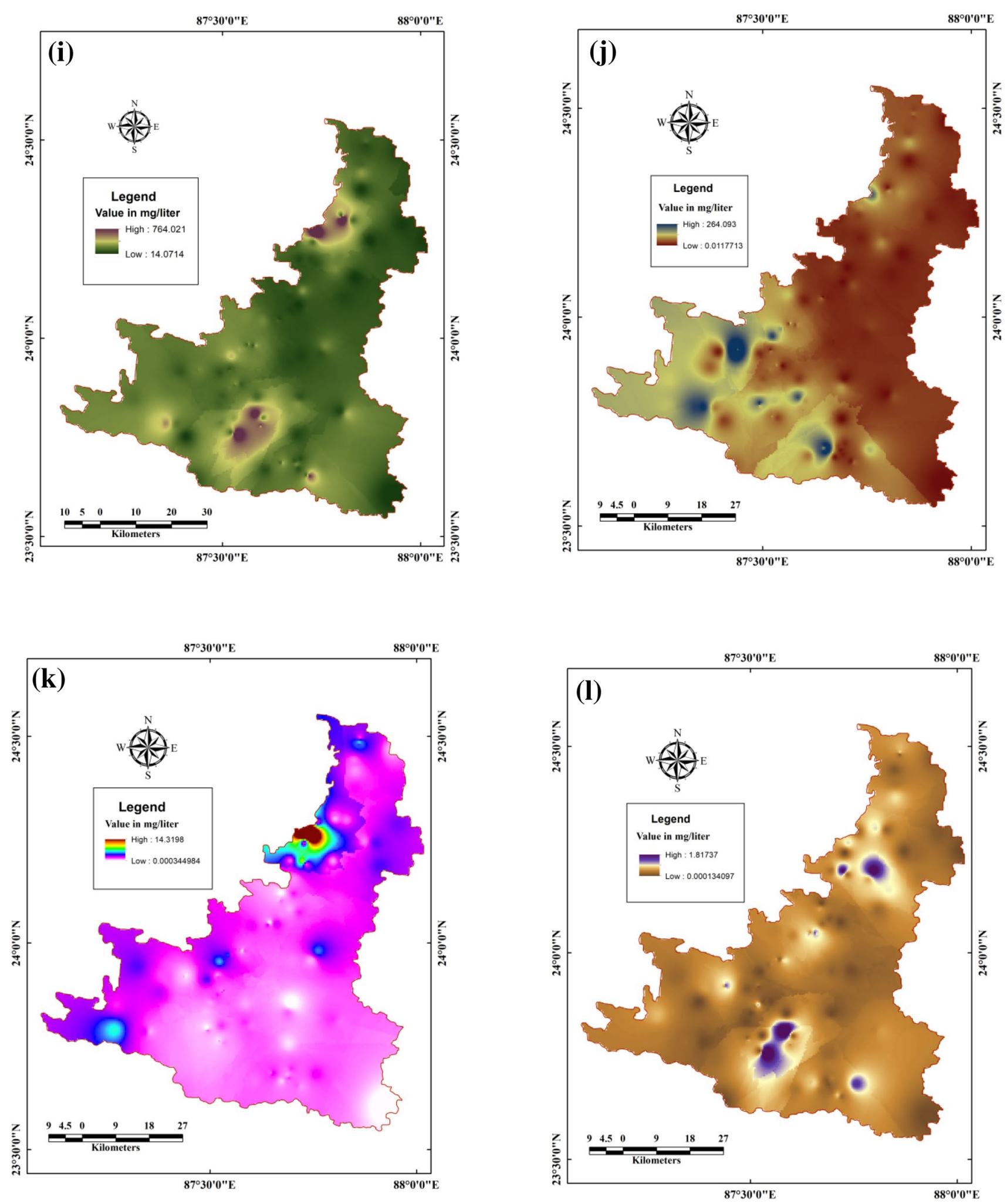

Fig. 4 (continued) 

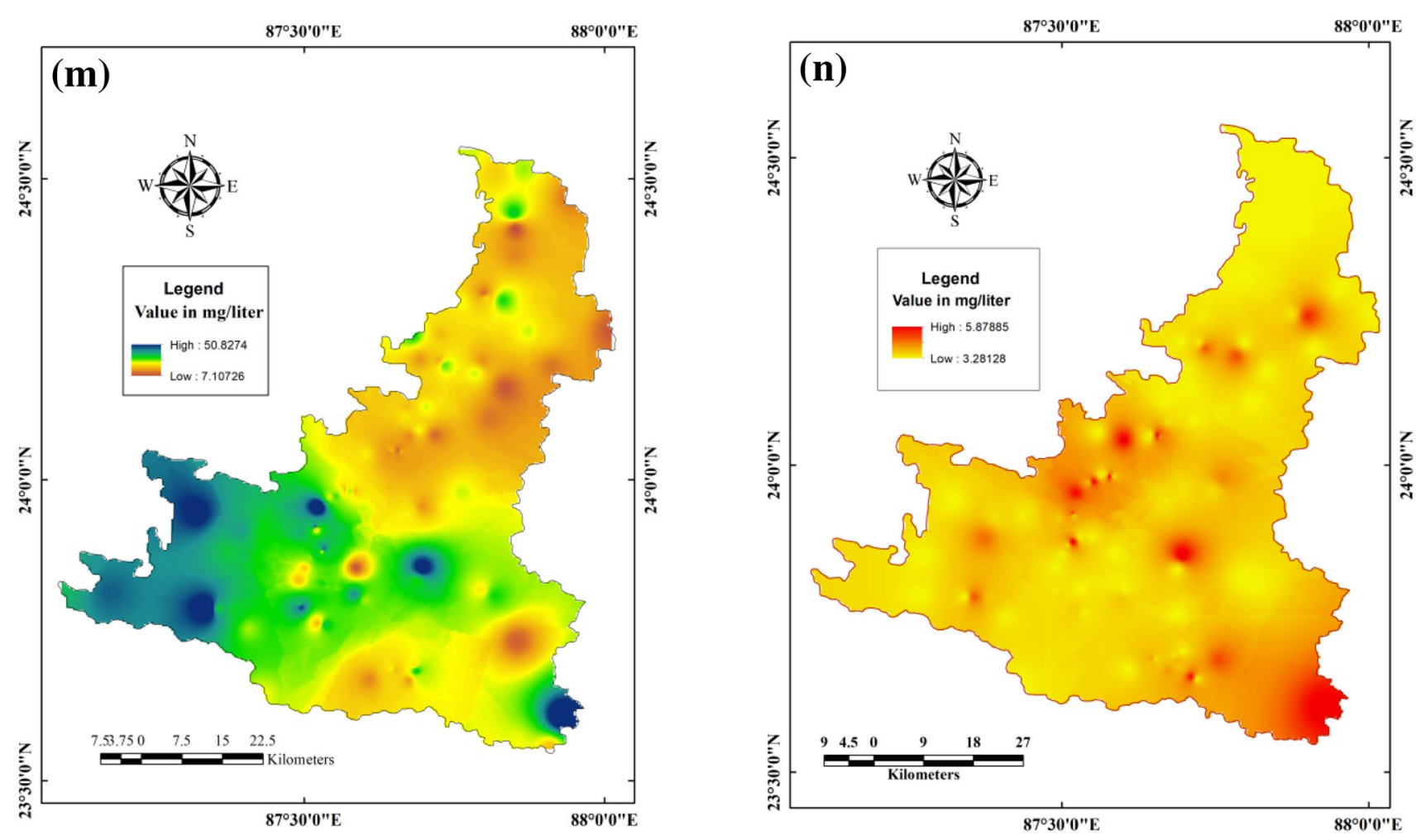

Fig. 4 (continued)
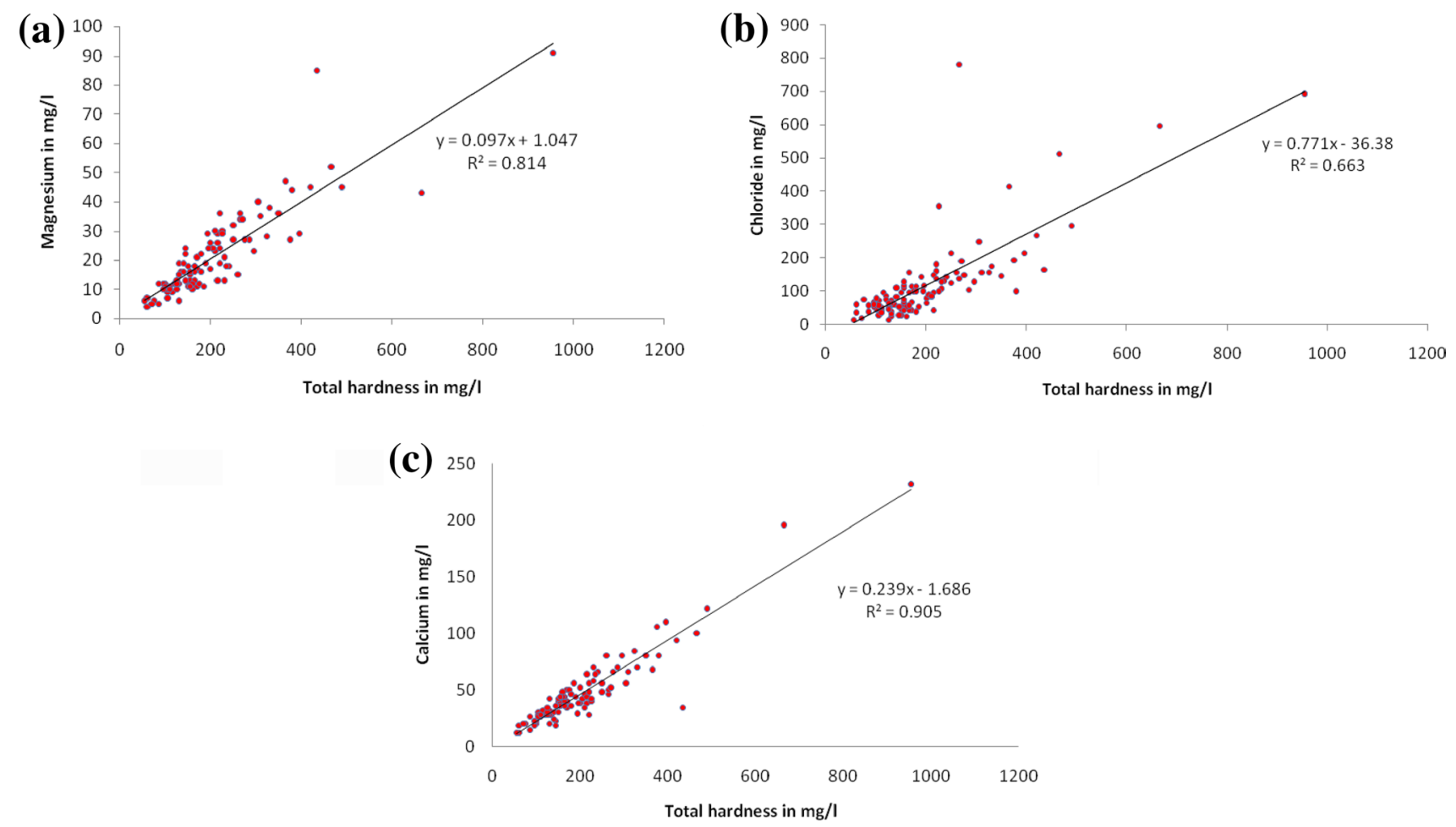

Fig. 5 a Relationship between total hardness and magnesium, $\mathbf{b}$ relationship between total hardness and chloride, $\mathbf{c}$ relationship between total hardness and calcium 
Table 3 Correlation coefficient matrix among groundwater hydro-chemical variables

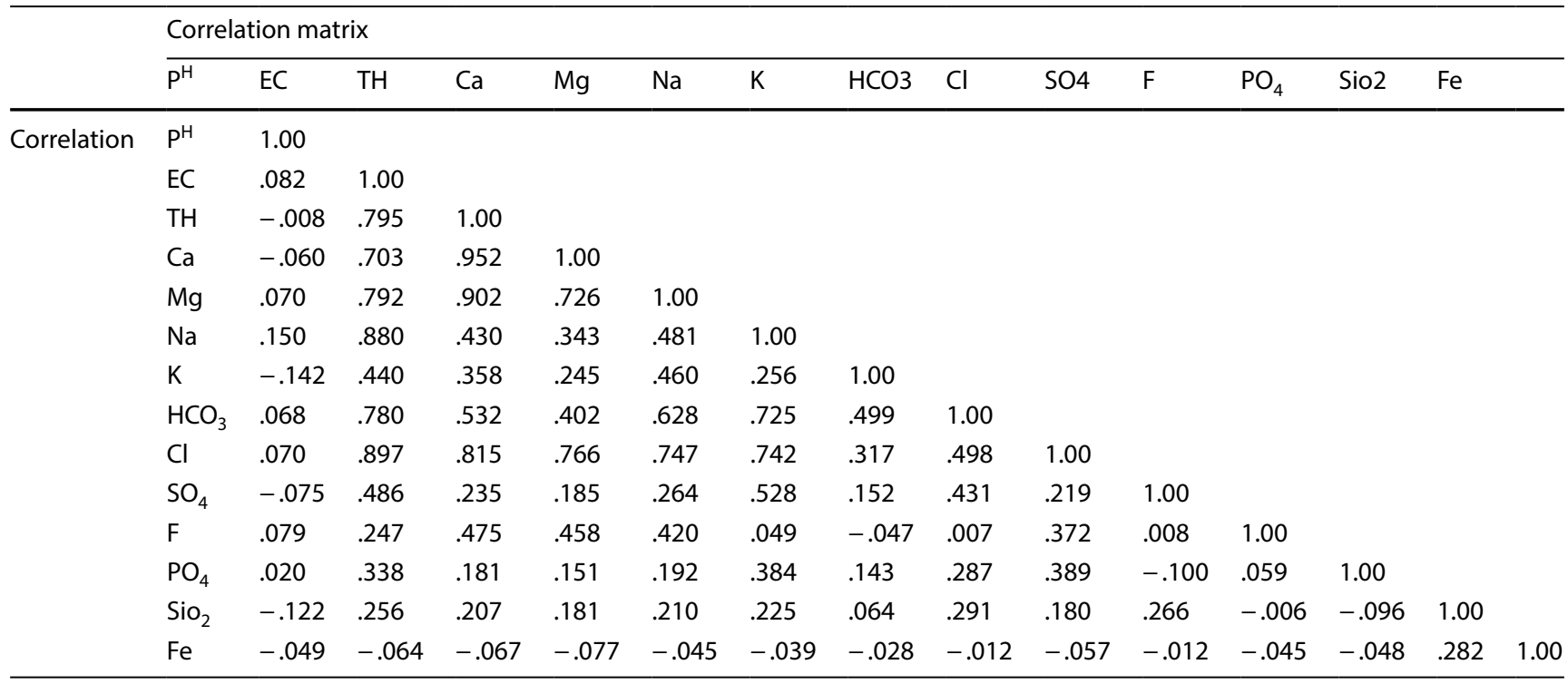

crystalline igneous rocks and alkaline soils which help to generate fluoride [34]. Fluoride above the permissible limit can be observed along the northwestern part of plateau fringe (Fig. 4k). WHO has set $15 \mathrm{mg} / \mathrm{l}$ as permissible limit of fluoride. But this part records $143 \mathrm{mg} / \mathrm{l}$ fluoride contamination, which has an adverse impact on the human health. Rajmahal trap with semiarid condition is responsible for heavy fluoride contamination in this region (Figs. 2 and $4 \mathrm{k})$.

Iron is of little concern as a health hazard, but still in excessive quantities it is considered as a nuisance [19]. The maximum acceptable limit of iron ranges between $03 \mathrm{mg} / \mathrm{l}$ to $10 \mathrm{mg} / \mathrm{l}$. In the study area, iron ranges from 32 to $58 \mathrm{mg} / \mathrm{l}$ which is basically above the permissible limit. The major source of iron in this part of study area is the presence of lateritic patch [21]. The maximum concentration of iron in the study is observed in the western and southeastern parts where laterite is predominant. High concentration of iron affects the taste of water and promotes the growth of iron bacteria [21].

\subsection{Principal component and factor analysis}

Factor analysis (FA) is the technique related to PCA, which helps to generate an unobserved variable which compiles in three or more observed variables. Therefore, factor analysis as statistical tool of principal component analysis has been taken into consideration to extract major chemicals influencing groundwater in Birbhum District.

To calculate factor analysis, the correlation matrix by Pearson has been used here. Based on the result of correlation, the positive and negative relations between variables can be identified. Table 3 shows the relational matrix between chemical variables of groundwater.

Strong positive correlation can be detected with the total hardness, calcium, magnesium and chloride. This relationship was shown in the previous section with the help of scatter diagram (Fig. 5a-c). Except this, chloride has the strong positive relationship with electrical conductivity, calcium, magnesium and sodium. Total hardness is also significantly related to electrical conductivity. Iron is negatively correlates with almost all the parameters expect silicon oxide Fluoride shares negative relation with potassium.

PCA has been calculated with the aid of Kaiser normalization which is the extract of five main principal components which act as the major factors influencing groundwater in this region. Five principal factors accounted for $7967 \%$ of the total variance in the hydro-chemical data.

Factor 1 explains $42 \%$ of the total variance, and high positive loading of total hardness, calcium and magnesium is shown in this factor. So, this factor explains the general water quality parameters which are utmost important for the drinking water. The chemical components, viz. $\mathrm{Mg}, \mathrm{Cl}$, $\mathrm{Na}$ and $\mathrm{SO}_{4}$, influence rate of evaporation, recharge and anthropogenic sources of the groundwater system $[6,71]$. Therefore, it can be concluded that Factor 1 represents the impact of geological variation and human impact on the groundwater chemistry in the concerned area. The study of Jalali [50] has also been reported that the $\mathrm{Na}$ and $\mathrm{Cl}$ ions are mostly originated from agricultural field mainly from the use of chemical fertilizer, animal waste and industrial pollutants. This factor is also related to the TDS variation [71]. Fluoride $(F)$ concentration is one of the important 
Table 4 Varimax rotated factor loading

\begin{tabular}{|c|c|c|c|c|c|}
\hline Variable & 1 & 2 & 3 & 4 & 5 \\
\hline $\mathrm{P}^{\mathrm{H}}$ & .017 & .159 & .134 & -.125 & -.800 \\
\hline EC & .594 & .763 & .200 & .025 & .051 \\
\hline $\mathrm{TH}$ & .911 & .316 & .055 & .014 & .153 \\
\hline $\mathrm{Ca}$ & .894 & .203 & .016 & .012 & .138 \\
\hline $\mathrm{Mg}$ & .784 & .422 & .099 & .013 & .148 \\
\hline $\mathrm{Na}$ & .224 & .868 & .260 & .048 & -.136 \\
\hline K & .167 & .377 & .218 & -.105 & .644 \\
\hline $\mathrm{HCO}_{3}$ & .250 & .800 & .195 & .069 & .175 \\
\hline $\mathrm{Cl}$ & .733 & .477 & .313 & .029 & -.015 \\
\hline $\mathrm{SO}_{4}$ & .035 & .739 & -.450 & .043 & .028 \\
\hline $\mathrm{F}$ & .749 & -.206 & -.078 & -.024 & -.240 \\
\hline $\mathrm{PO}_{4}$ & .098 & .176 & .860 & -.036 & .000 \\
\hline $\mathrm{SiO}_{2}$ & .720 & .314 & -.260 & .688 & .105 \\
\hline $\mathrm{Fe}$ & -.070 & -.102 & .116 & .874 & -.013 \\
\hline Variance (\%) & 42.009 & 12.105 & 10.021 & 8.087 & 7.454 \\
\hline $\begin{array}{l}\text { Cumulative vari- } \\
\text { able (\%) }\end{array}$ & 42.009 & 54.114 & 64.135 & 72.222 & 79.676 \\
\hline
\end{tabular}

Factor loadings $>.7$ are marked by bold font

harmful hydro-chemical elements as it has adverse effect on human health $[56,67,89,105,114]$. According to the report of CGWB, the villages adjacent to the plateau fringe area of Birbhum District have high concentration of fluoride. So, fluoride has been extracted here as first factor loading with high positive value (Table 4).

$\mathrm{EC}, \mathrm{Na}, \mathrm{SO}_{4}$ and $\mathrm{HCO}_{3}$ have been loaded as second factor which comprises $11.9 \%$ of the total variance. There is strong positive correlation between EC and NA $(r=088)$. This is due to anthropogenic activities which add significant amount of ion to the groundwater. The third factor contributes only $10 \%$ of the total variance $\mathrm{PO}_{4}$ which is positively loaded in this factor. There are two sources of $\mathrm{PO}_{4}$ where natural sources include deposition of atmospheric, chemical decomposition of rocks and minerals and biomass decay. On the other hand, anthropogenic sources include use of chemical fertilizers and animal wastes, etc. Fe or iron has been loaded as fourth factor which explains only $8 \%$ of the total variance. Iron is one of the major constituents of groundwater which basically originated from lateritic geological formation in the study area. Previously it was mentioned that Fe is not harmful to health up to a certain limit, but it may badly affect cloths and utensils. The southeastern part of the study area is affected by high content of iron, so it has been loaded in the fourth factor of the groundwater chemistry. $\mathrm{P}^{\mathrm{H}}$ is loaded as the last and fifth factor which accounts for $7.2 \%$ among the total variance. Correlation matrix shows that $\mathrm{P}^{\mathrm{H}}$ is negatively correlated with most of the analyzed chemical components
Table 5 Weight or coefficient of each components

\begin{tabular}{lrrrrr}
\hline & \multicolumn{6}{l}{ Component } \\
\cline { 2 - 6 } & \multicolumn{1}{l}{ 1 } & \multicolumn{1}{l}{3} & \multicolumn{1}{l}{4} \\
\hline $\mathrm{PH}$ & .064 & -.009 & -.628 & .218 & .479 \\
$\mathrm{EC}$ & .978 & .146 & -.089 & .003 & -.005 \\
$\mathrm{TH}$ & .890 & -.357 & .179 & -.055 & .038 \\
$\mathrm{Ca}$ & .797 & -.429 & .183 & -.015 & .012 \\
$\mathrm{Mg}$ & .873 & -.197 & .142 & -.104 & .070 \\
$\mathrm{Na}$ & .776 & .435 & -.314 & .135 & -.010 \\
$\mathrm{~K}$ & .465 & .237 & .262 & -.466 & -.325 \\
$\mathrm{HCO}$ & .759 & .429 & -.006 & --.089 & -.038 \\
$\mathrm{Cl}$ & .900 & -.163 & -.097 & .145 & -.129 \\
$\mathrm{SO}_{3}$ & .559 & .456 & -.115 & -.199 & .406 \\
$\mathrm{~F}$ & .369 & -.696 & .002 & .110 & .267 \\
$\mathrm{PO}_{4}$ & .376 & -.046 & -.413 & .488 & -.592 \\
$\mathrm{SiO}_{2}$ & .280 & .328 & .560 & .381 & .255 \\
$\mathrm{Fe}$ & -.054 & .198 & .457 & .672 & .020 \\
\hline
\end{tabular}

Extraction method: principal component analysis

which are reflected by the negative factor loaded and present in fifth factor.

The weights or coefficients are very important because it help to understand the importance of the variables. Table 5 shows the weight of each components as well as variables.

Table 5 shows that if component 1 is $Y_{1}$, then

$Y_{1}=\mathrm{P}^{\mathrm{H}} \times 0.064+\mathrm{EC} \times 0.978+\mathrm{TH} \times 0.890 \ldots n$

In the same way, we can get the weight of each variable for each component.

\subsection{Spatial pattern of controlling factors}

In this section, the spatial concentration of each factor has been analyzed. This analysis is very important because with the help of this explanation, hydrologist can easily understand the qualitative upgradation and degradation of the groundwater, and also, this analysis helps to make sure what kind of planning and management should be needed for the development of the quality of the groundwater?

Fluoride strongly influences Factor 1 , as a result in Factor 1 map (Fig. 6a) shows the high concentration of fluoride in the northwestern part of the study area. So, in Birbhum district it has been proved that fluoride concentration is one of the major determinants to control groundwater quality in the northwestern part, where plateau fringe of Jharkhand present.

Factor 2 includes $\mathrm{EC}, \mathrm{Na}, \mathrm{HCO}_{3}$ and $\mathrm{SO}_{4}$, which are mainly concentrated in the southwestern part of the study area. $\mathrm{SO}_{4}$ is the important chemical components. Sodium 

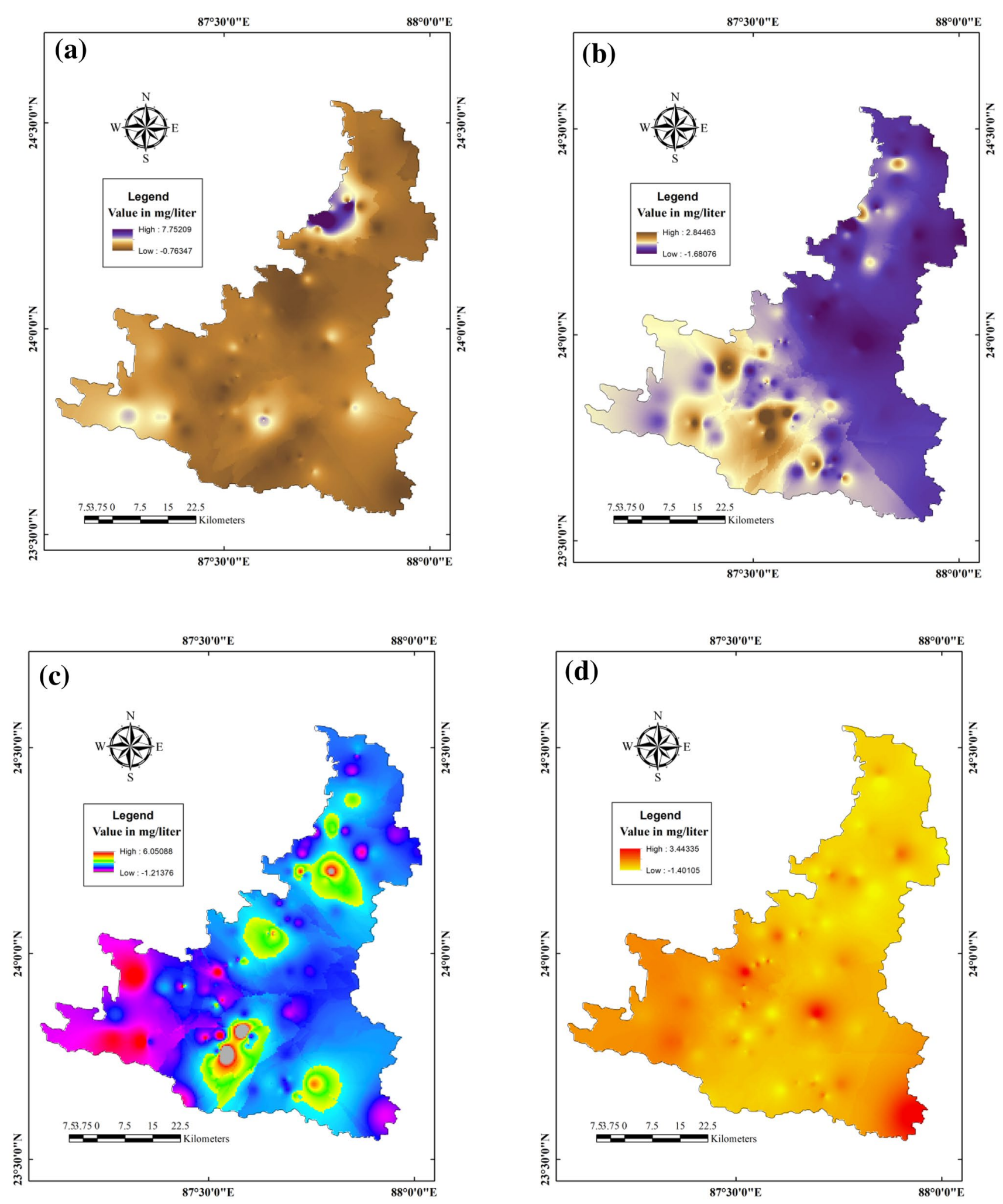

Fig. 6 a Factor 1, b Factor 2, c Factor 3, d Factor, 4 e Factor 5 


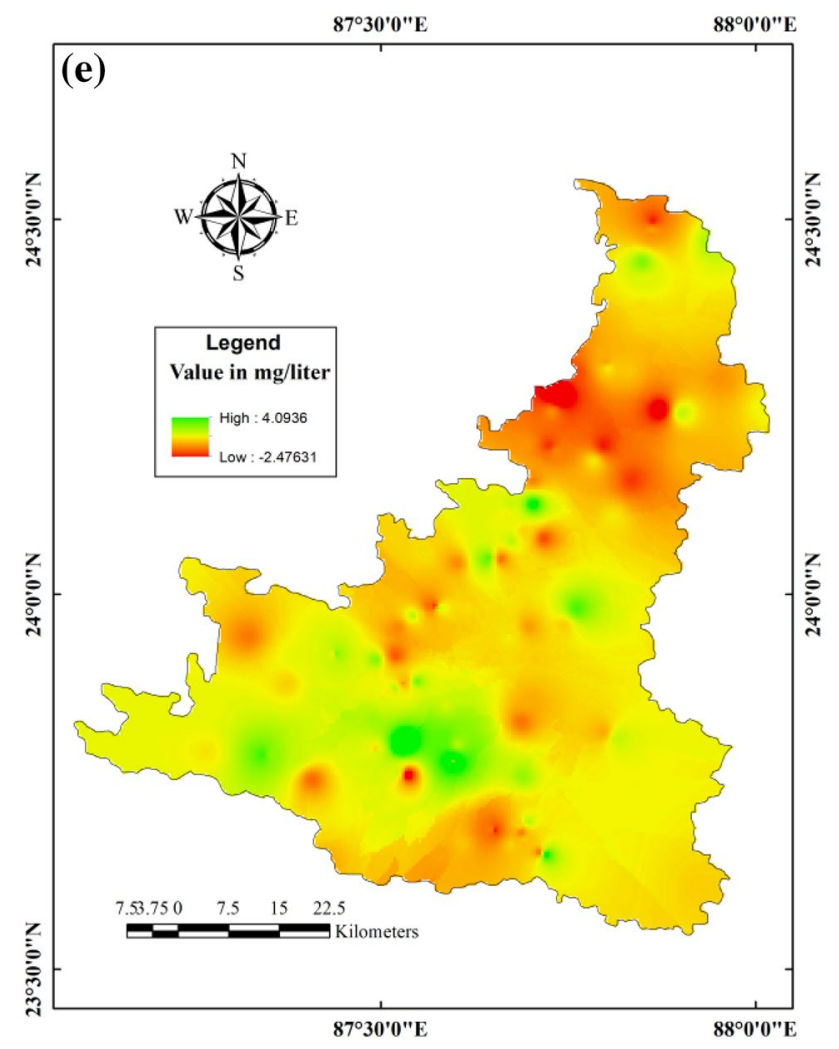

Fig. 6 (continued)

is very effective in irrigation and drinking purposes. Higher amount of sodium makes the water unsuitable for irrigation purpose, and high sodium content in drinking water causes several health problems like high blood pressure, hypertension, nervous disorder, etc. Higher $\mathrm{HCO}_{3}$ content may promote the alkalinity level, which may affect human health; high amount of sulfate makes bitter taste and bad odor of water. So, concentration of these chemicals in the southwestern part of the study area must be the prime concern for the hydrologist.

Factor 3 extracts only phosphate. Phosphate is a nontoxic element for the human health until they are present in very high levels. Digestive problems could occur from extremely high levels of phosphate. Phosphate as a third determinant factor is highly concentrated in the southern and northern parts of the study area.

Factor 4 comprises iron, which initially is not harmful for the human health, but high amount of iron, i.e., $>.3 \mathrm{mg} / \mathrm{l}$ in drinking water causes serious health problems like hemochromatosis, digestion problem, diabetes, skin diseases, etc. Figure $6 \mathrm{~d}$ shows high concentration of iron as fourth factor in the southwestern part of the study area, where lateritic geology is predominant. So, it is also a major concern to the hydrologist for the optimization of iron content in this part.

Factor 5 helps to extract $\mathrm{P}^{\mathrm{H}}$. It is an important chemical component of the drinking water. The limit of $\mathrm{P}^{\mathrm{H}}$ in the study area is in optimum condition, so it is not the great matter of concern.

The above analysis reveals that the spatiality of the factors makes this study more relevant rather than the implementation of statistical tools.

\subsection{Cluster analysis}

Cluster analysis is a sort of clustering or grouping technique in which cases or observations can be grouped according to the similarity for the measured variable.

There are various methods for the cluster analysis like two-step clustering, k-means clustering, cluster, etc. But hierarchical cluster analysis is a widely used method for the identification of grouping of chemical variables within groundwater. This method basically helps to group variables into clusters based on similarities in such a way that individual cluster depicts a specific process in a system $[71,116]$. Hierarchical clustering is one of these. The level of similarity has been presented through dendrogram. Euclidean distance has been chosen to measure the distance between sample sites, and Ward's method has been chosen as cluster method which has been described in method section. Except this, Ward's method has been successfully applied to form clusters that are homogeneous and geochemically detachable [23]. Based on standard major cations and other trace elements, cluster analysis has been carried out to split water sample into a number of groups with similar hydrochemical characteristics.

As we know, the major aim of the cluster analysis is to sort elements into groups or clusters. Therefore, in this study two dendrograms have been prepared. One dendrogram is shown to make grouping or clustering among the sample sites; it means the sample sites having homogeneous chemical composition form a single group (Fig. 6). Based on the sample-wise cluster analysis dendrogram (Fig. 7), it is reported that there are three clusters present in the dendrogram, among which $63.55 \%$ sample sites are clustered in cluster 1, $22.897 \%$ are in cluster 2 and only $13.55 \%$ sample sites are clustered in cluster 3.

On the other hand, another dendrogram (Fig. 8) shows the grouping of chemical components, where $\mathrm{P}^{\mathrm{H}}, \mathrm{PO}_{4}, \mathrm{SiO}_{2}$ and Fe are grouped into cluster 1 and occupy $23.07 \%$. In cluster 2, $\mathrm{EC}, \mathrm{Na}, \mathrm{K}, \mathrm{HCO}_{3}, \mathrm{Cl}$ and $\mathrm{SO}_{4}$ are grouped and cluster 2 comprises $46.15 \%$ of the total grouping. On the other 

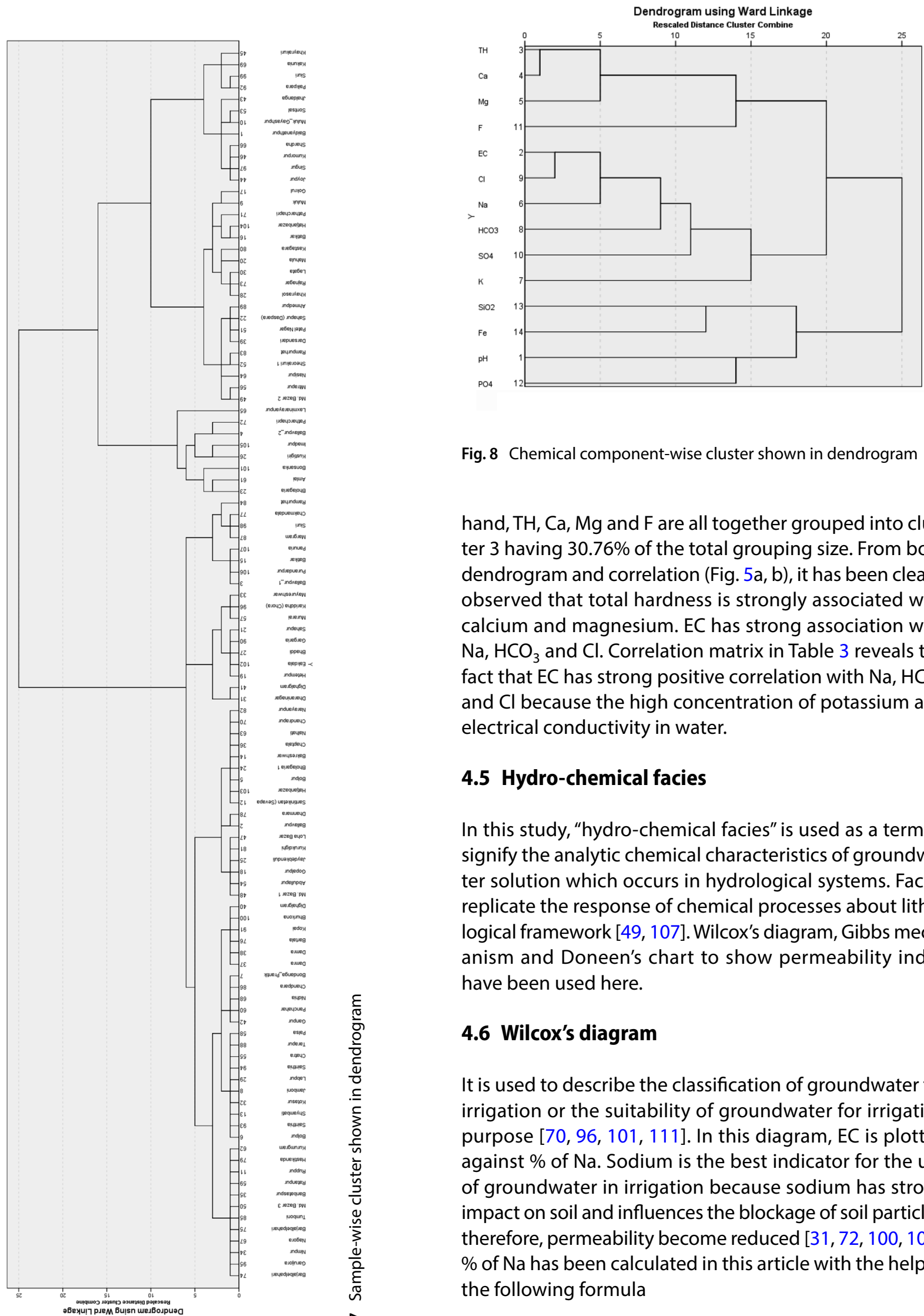

Fig. 8 Chemical component-wise cluster shown in dendrogram

hand, $\mathrm{TH}, \mathrm{Ca}, \mathrm{Mg}$ and $\mathrm{F}$ are all together grouped into cluster 3 having $30.76 \%$ of the total grouping size. From both dendrogram and correlation (Fig. 5a, b), it has been clearly observed that total hardness is strongly associated with calcium and magnesium. EC has strong association with $\mathrm{Na}, \mathrm{HCO}_{3}$ and $\mathrm{Cl}$. Correlation matrix in Table 3 reveals the fact that $\mathrm{EC}$ has strong positive correlation with $\mathrm{Na}, \mathrm{HCO}_{3}$ and $\mathrm{Cl}$ because the high concentration of potassium and electrical conductivity in water.

\subsection{Hydro-chemical facies}

In this study, "hydro-chemical facies" is used as a term to signify the analytic chemical characteristics of groundwater solution which occurs in hydrological systems. Facies replicate the response of chemical processes about lithological framework [49, 107]. Wilcox's diagram, Gibbs mechanism and Doneen's chart to show permeability index have been used here.

\subsection{Wilcox's diagram}

It is used to describe the classification of groundwater for irrigation or the suitability of groundwater for irrigation purpose $[70,96,101,111]$. In this diagram, EC is plotted against $\%$ of $\mathrm{Na}$. Sodium is the best indicator for the use of groundwater in irrigation because sodium has strong impact on soil and influences the blockage of soil particles; therefore, permeability become reduced $[31,72,100,106]$. $\%$ of $\mathrm{Na}$ has been calculated in this article with the help of the following formula 


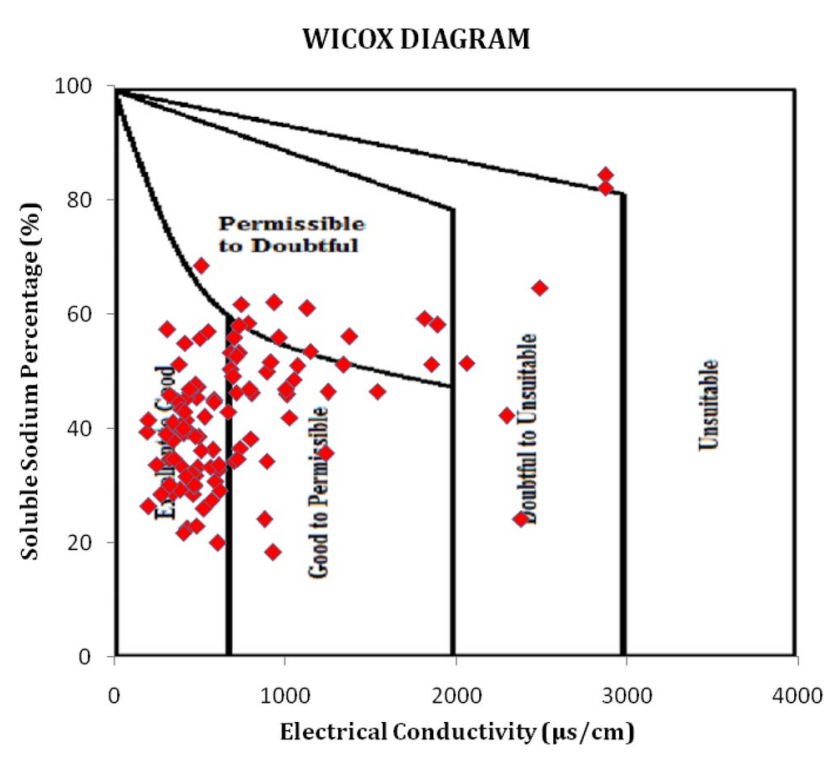

Fig. 9 Wilcox's diagram

$\% \mathrm{Na}=\left(\frac{\mathrm{Na}^{+}+\mathrm{K}^{+}}{\mathrm{Ca}^{2+}+\mathrm{Mg}^{2+}+\mathrm{K}^{+}+\mathrm{Na}^{+}}\right) \times 100$

where all the ionic concentrations are present in meq per liter

Now, the calculated \% $\mathrm{Na}$ and electrical conductivity measured in $\mu \mathrm{s} / \mathrm{cm}$ have been plotted in Wilcox's diagram (Fig. 8).

Figure 9 depicts that about 50\% sample are in excellent to good category, while $25 \%$ sample present in the good to permissible, $20 \%$ samples are under the category of and $5 \%$ belongs to the category of doubtful to unsuitable. So, Wilcox's diagram proves that groundwater of the most part of the district is very much suitable for irrigation purpose.

\subsection{Gibbs mechanism}

The chemical compositions of the groundwater largely depend on the lithological character of the region. Gibbs in 1970 proposed a diagram to represent major anions and cations and set the relationship between water composition and lithology $[41,62,81,84]$. Gibbs diagram depicts three major mechanisms which regulate the chemical composition of the groundwater, which are a. evaporation dominance, b. precipitation dominance and c. rock dominance. Gibbs ratio can be found out with the help of the following formulas.

Gibbs Ratio I(for anions) $=\frac{\mathrm{Cl}^{-}}{\left(\mathrm{Cl}^{-}+\mathrm{HCO}_{3}^{-}\right)}$
Gibbs Ratio II (for cations $)=\frac{\mathrm{Na}^{+}+\mathrm{K}^{+}}{\left(\mathrm{Na}^{+}+\mathrm{K}^{+}+\mathrm{Ca}^{2+}\right)}$

Figure $10 \mathrm{a}$ and $\mathrm{b}$ reveals the fact that about $68 \%$ samples belong to the category of rock dominance and the rest $32 \%$ fall in precipitation dominance category. So, this result indicates that the major portion of the samples of the study area is influenced by weathering of the rocks and resultant mixing of minerals. This phenomenon is basically observed in the western part of the district.

\subsection{Permeability index (PI)}

Percolation index is the diagrammatic presentation of hydro-chemical facies which helps to identify whether the groundwater of the study area is suitable for irrigation or not. For the formulation of the permeability index, the chemical components such as sodium, calcium, magnesium and bicarbonate are the essential because irrigation water is positively affected by the above-mentioned chemical elements. Therefore, to calculate permeability index, the following formula has been employed.

$\mathrm{PI}=\frac{\left(\mathrm{Na}^{+}+\sqrt{\mathrm{HCO}_{3}^{-}}\right) \times 100}{\mathrm{Na}+\mathrm{Ca}^{2+}+\mathrm{Mg}^{2+}}$

Percolation index is represented by Doneen's chart [26, 85], in which three classes have been depicted, where class I and class II are considered as good for irrigation and class III water represents as unsuitable for irrigation.

Figure 11 explains that about 99\% samples remain in class I and only $1 \%$ present remain in class III. Hence, Doneen's chart depicts that all the samples are suitable for irrigation in the study area.

\section{Conclusion}

This study helps to reach various conclusions; for example, the implementation of multivariate statistics helps to reduce the dimension of the large data set and extract only few important determinants to control the groundwater quality. As five components account $80 \%$ of the total variance, those five components have been taken as major quality controlling factors. In this respect, this study has a separate mathematical or statistical base.

But in geographical point of view, the statistical analysis helps us to find the spatiality of major determinants factors and also helps to formulate whether planning should necessary or not. On $\mathrm{n}$ the basis of the above analysis, a geographer, an environmentalist and hydrologist can easily take decisions for the optimization of groundwater 
Fig. 10 a and $\mathbf{b}$ Mechanism to control the chemistry of groundwater
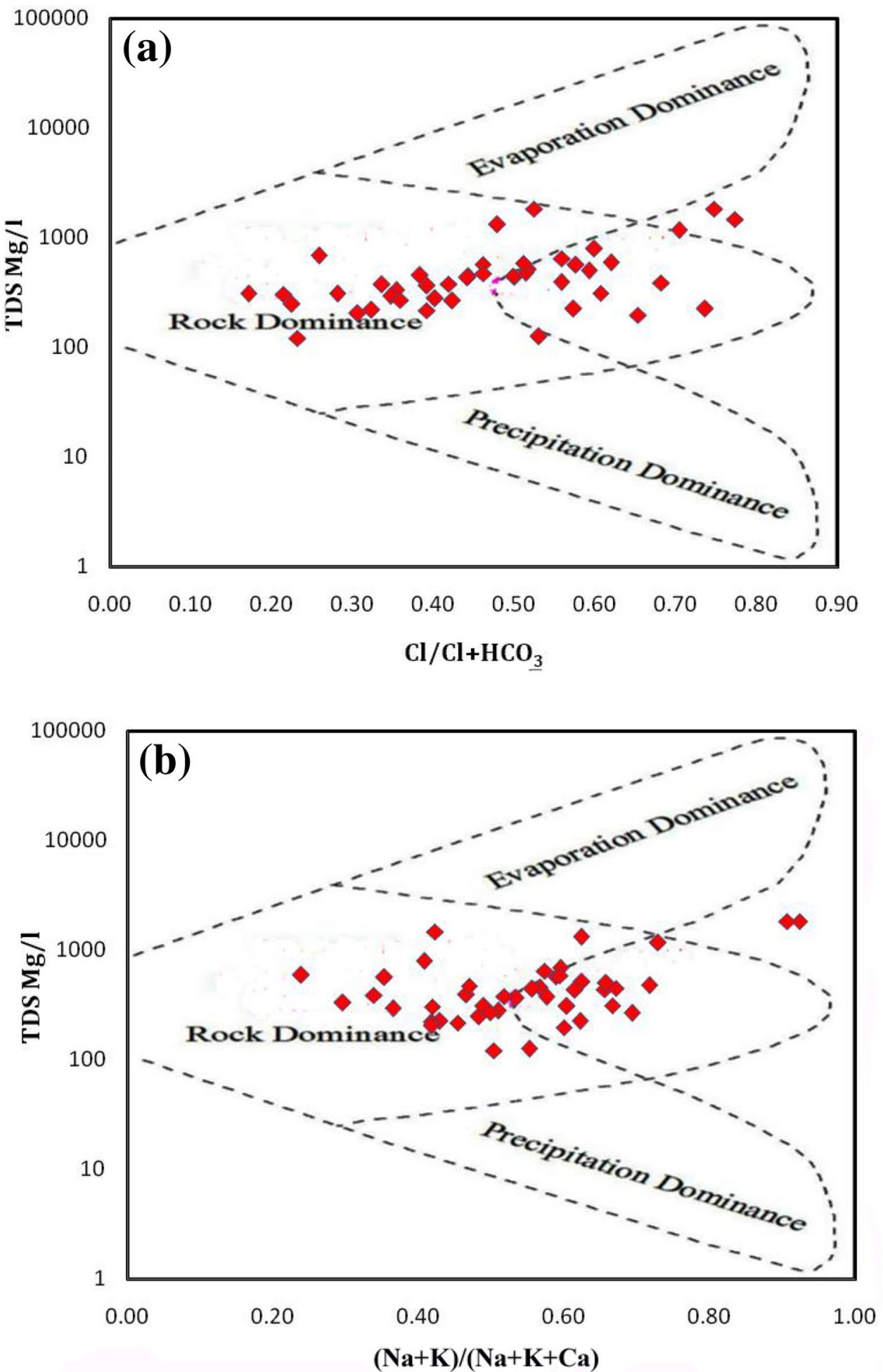

quality, wherever it necessary. Moreover, different hydrological diagrams help to explain different aspects of groundwater, which is geographically very important and useful.

Therefore, assessment of groundwater quality by using statistical tool and diagrammatic presentation is not just the general study, but it helps to indentify the most vulnerable zone in terms of groundwater quality which may badly affect the human body and subjected to worse situation. So, this kind of assessment must be helpful to the district planner, hydrologist, geologist and other administrative officers for the betterment and sustainable 

sify the irrigation water
Fig. 11 Doneen's chart to clas-

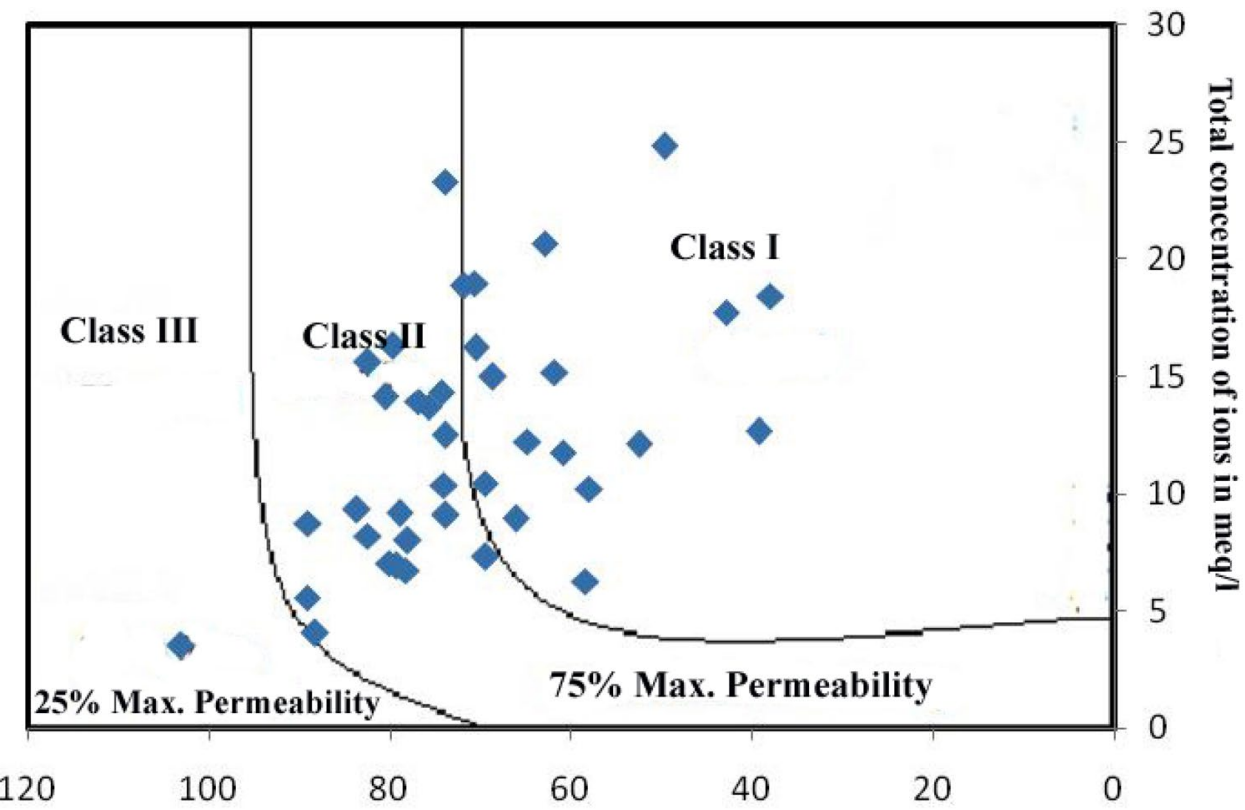

development of groundwater resource for the common people. Moreover, the findings of this study may be valuable for government and local authorities.

Acknowledgements The authors express their thanks to Dr Gopal Chandra Debnath, retired professor, Department of Geography, Visva-Bharati, Dr Gautam Sen, Associate Professor, Hiralal Bhakat College, Nalhati, Birbhum and Dr Tirthankar Ghosh, Assistant Professor, Department of Statistics, Visva-Bharati, and Santiniketan for their valuable suggestion and extended help in every step of the research. The authors are very thankful to the Central Groundwater Board (CGWB) for providing necessary data.

\section{Compliance with ethical standards}

Conflict of interest The authors declare that there is no conflict of interest.

\section{References}

1. Abdelkader R, Larbi D, Rihab H et al (2010) Geochemical characterization of groundwater from shallow aquifer surrounding Fetzara Lake N. E. Algeria. Arab J Geosci 5:1-13. https://doi. org/10.1007/s12517-010-0202-6

2. Adhikary P, Chandrasekharan H, Chakraborty D et al (2008) Statistical approaches for hydrogeochemical characterization of groundwater in West Delhi, India. Environ Monit Assess 154:41-52. https://doi.org/10.1007/s10661-008-0376-5

3. Aghazadeh N, Mogaddam A (2010) Assessment of Groundwater Quality and its Suitability for Drinking and Agricultural Uses in the Oshnavieh Area, Northwest of Iran. J Environ Prot 01:30-40. https://doi.org/10.4236/jep.2010.11005

4. Ahamed A (2017) Evaluation of graphical and multivariate statistical methods for classification and evaluation of groundwater in Alathur block, Perambalur district, India.
Appl Ecol Environ Res 15:105-116. https://doi.org/10.15666/

5. Ahamed A, Loganathan K (2017) Water quality concern in the Amaravathi River Basin of Karur district: a view at heavy metal concentration and their interrelationships using geostatistical and multivariate analysis. Geol Ecol Landsc 1:19-36. https:// doi.org/10.1080/24749508.2017.1301055

6. Aiman AL, Mohamed EK (2010) Groundwater investigation in Awlad Salameh, Southern Sohag, Upper Egypt. Earth Sci Res J 14:63-75

7. Alberto W, María del Pilar D, Maŕia Valeria A et al (2001) Pattern recognition techniques for the evaluation of spatial and temporal variations in water quality. A case study. Water Res 35:2881-2894. https://doi.org/10.1016/s0043-1354(00)00592 $-3$

8. Alcamo J, Flörke M, Märker M (2007) Future long-term changes in global water resources driven by socio-economic and climatic changes. Hydrol Sci J 52:247-275. https://doi. org/10.1623/hysj.52.2.247

9. Azizullah A, Khattak M, Richter P, Häder D (2011) Water pollution in Pakistan and its impact on public health-a review. Environ Int 37:479-497. https://doi.org/10.1016/j.envin t.2010.10.007

10. Bai W, Kong L, Guo A (2013) Effects of physical properties on electrical conductivity of compacted lateritic soil. J Rock Mech Geotech Eng 5:406-411. https://doi.org/10.1016/j.jrmge .2013 .07 .003

11. Batayneh A, Al-Taani A (2015) Integrated resistivity and water chemistry for evaluation of groundwater quality of the Gulf of Aqaba coastal area in Saudi Arabia. Geosci J 20:403-413. https ://doi.org/10.1007/s12303-015-0053-y

12. Bear J (1979) Hydraulics of groundwater. McGraw-Hill series in water resources and environmental engineering. McGraw-Hill, New York

13. Bureau of Indian Standards (2012) Indian standard drinking water-specification, 2nd edn. Bureau of Indian Standards, Manak Bhawan, pp 1-12 aeer/1503_105116 
14. Cangelosi R, Goriely A (2007) Component retention in principal component analysis with application to CDNA microarray data. Biol Direct 2:2. https://doi.org/10.1186/1745-6150-2-2

15. Cattle RB (1966) The scree test for the number factors. Multivar Behav Res 32:245-276

16. CGWB (2009) Central groundwater board: Bhu-Jal news-quarterly journal of central ground water board with the objective to disseminate information and highlight various activities and latest technical advances in the field of Ground Water. Q J 24:12-17

17. Chakraborti D, Rahman M, Ahamed S et al (2016) Arsenic contamination of groundwater and its induced health effects in Shahpur block, Bhojpur district, Bihar state, India: risk evaluation. Environ Sci Pollut Res 23:9492-9504. https://doi. org/10.1007/s11356-016-6149-8

18. Chen K, Jiao J, Huang J, Huang R (2007) Multivariate statistical evaluation of trace elements in groundwater in a coastal area in Shenzhen, China. Environ Pollut 147:771-780. https://doi. org/10.1016/j.envpol.2006.09.002

19. Dart FJ (1974) The hazard of iron. Water and Pollution Control, Ottawa

20. Das N, Mukhopadhyay S (2018) Application of multi-criteria decision making technique for the assessment of groundwater potential zones: a study on Birbhum district. Environment, Development and Sustainability, West Bengal. https://doi. org/10.1007/s10668-018-0227-7

21. Das S, Nag S (2015) Application of multivariate statistical analysis concepts for assessment of hydrogeochemistry of groundwater-a study in Suri I and II blocks of Birbhum District, West Bengal, India. Appl Water Sci 7:873-888. https://doi. org/10.1007/s13201-015-0299-6

22. Das S, Metha BC, Das PK, Srivastava SK, Samanth SK (1998) Source of high fluoride in ground water of Anugul, Dhenkenal District, Orrissa. Pollut Res 17:385-392

23. Dhakate R, Mahesh J, Sankaran S, Gurunadha Rao V (2013) Multivariate statistical analysis for assessment of groundwater quality in Talcher Coalfield area, Odisha. J Geol Soc India 82:403-412. https://doi.org/10.1007/s12594-013-0167-7

24. Dhindsa SS, Bheel P, Musturia Y (2004) Hydro-chemical study of ground water quality variation in Tonk District, Rajasthan. Indian J Environ Ecoplanning 8:129-136

25. Domenico PA, Schwartz FW (1990) Physical and chemical hydrogeology. Wiley, New York, p 824

26. Doneen LD (1965) Notes on water quality in agriculture. Published as water science and Engineering. Paper 4001, Department of Water Science and Engineering, University of California

27. Dunteman GH (1989) Principal components analysis. Sage Publication Inc, Thousand Oaks

28. El Alfy M, Abdalla F, Moubark K, Alharbi T (2018) Hydrochemical equilibrium and statistical approaches as effective tools for identifying groundwater evolution and pollution sources in arid areas. Geosci J 23:299-314. https://doi.org/10.1007/ s12303-018-0039-7

29. Gangopadhyay S, Das Gupta A, Nachabe M (2001) Evaluation of ground water monitoring network by principal component analysis. Ground Water 39:181-191. https://doi.org/10.1111/ j1745-65842001tb02299x

30. Garode AM, Nanoty VD, Bodhankar MG (1998) Bacteriological status of drinking water in and around Chikhli Town of Buldana District, Maharashtra. Pollut Res 17:293-294

31. Gibrilla A, Bam E, Adomako D et al (2011) Application of water quality index (WQI) and multivariate analysis for groundwater quality assessment of the birimian and cape coast granitoid complex: Densu River Basin of Ghana. Water Qual Expo Health 3:63-78. https://doi.org/10.1007/s12403-011-0044-9
32. Grande J, González A, Beltrán R, Sánchez-Rodas D (1996) Application of factor analysis to the study of contamination in the aquifer system of Ayamonte-Huelva (Spain). Ground Water 34:155-161. https://doi.org/10.1111/j1745-65841996tb01875x

33. Güler C, Thyne G (2004) Hydrologic and geologic factors controlling surface and groundwater chemistry in Indian WellsOwens Valley area, southeastern California, USA. J Hydrol 285:177-198. https://doi.org/10.1016/j.jhydrol.2003.08.019

34. Handa B (1975) Geochemistry and genesis of fluoride-containing ground waters in India. Ground Water 13:275-281. https:// doi.org/10.1111/j.1745-6584.1975.tb03086.x

35. Helena B (2000) Temporal evolution of groundwater composition in an alluvial aquifer (Pisuerga River, Spain) by principal component analysis. Water Res 34:807-816. https://doi. org/10.1016/s0043-1354(99)00225-0

36. Hossain M, Selim Reza A, Lutfun-Nessa M, Ahmed S (2013) Factor and cluster analysis of water quality data of the groundwater wells of Kushtia, Bangladesh: implication for arsenic enrichment and mobilization. J Geol Soc India 81:377-384. https:// doi.org/10.1007/s12594-013-0048-0

37. Jain CK (2002) Arsenic contamination in ground water: Indian scenario. Indian J Environ Health 44:238-243

38. Jain CK (2004) Ground water quality of District Dehradun, Uttaranchal. Indian J Environ Ecoplanning 8:475-484

39. Jain CK (2004) Irrigation water quality in District Dehradun, Uttaranchal. Indian J Environ Ecoplanning 8:319-326

40. Jain CK (2004) Trace element contamination in ground water of District Dehradun, Uttaranchal. Indian J Environ Ecoplanning 8:597-605

41. Jain CK, Bandyopadhyay A, Bhadra A (2010) Assessment of ground water quality for drinking purpose, District Nainital, Uttarakhand, India. Environ Monit Assess 166:663-676

42. Jain CK, Bhatia KKS, Kumar SR (2000) Ground water contamination in Greater Guwahati, Assam. Indian J Environ Prot 20:641-648

43. Jain CK, Bhatia KKS, Kumar V (2000) Ground water quality in Sagar district, Madhya Pradesh. Indian J Environ Health 42:151-158

44. Jain CK, Bhatia KKS, Kumar CP, Purandara BK (2003) Ground water quality in Malprabha sub-basin, Karnataka. Indian J Environ Prot 23:321-329

45. Jain CK, Kumar CP, Sharma MK (2003) Ground water quality in Ghataprabha Command Area, Karnataka. Indian J Environ Ecoplanning 7:251-262

46. Jain CK, Kumar CP, Sharma MK (2003) Irrigation water quality in Ghataprabha command area, Karnataka. Indian J Environ Ecoplanning 7:409-420

47. Jain CK, Kumar S, Rao YRS (2004) Trace element contamination in a coastal aquifer of Andhra Pradesh. Pollut Res 23:13-23

48. Jain CK, Sharma MK, Bhatia KKS, Seth SM (2000) Ground water pollution-endemic of fluorosis. Pollut Res 19:505-509

49. Jain C, Bandyopadhyay A, Bhadra A (2009) Assessment of ground water quality for drinking purpose, District Nainital, Uttarakhand, India. Environ Monit Assess 166:663-676. https ://doi.org/10.1007/s10661-009-1031-5

50. Jalali M (2008) Geochemistry characterization of groundwater in an agricultural area of Razan, Hamadan, Iran. Environ Geol 56:1479-1488. https://doi.org/10.1007/s00254-008-1245-9

51. Jameel A, Sirajudeen J (2006) Risk Assessment of physicochemical contaminants in groundwater of Pettavaithalai Area, Tiruchirappalli, Tamilnadu - India. Environ Monit Assess 123:299-312. https://doi.org/10.1007/s10661-006-9198-5

52. Jeen S, Kim J, Ko K et al (2001) Hydrogeochemical characteristics of groundwater in a mid-western coastal aquifer system, Korea. Geosci J 5:339-348. https://doi.org/10.1007/bf02912705 
53. Kaple RD, Patode HS, Panaskar DB (1998) Ground water quality in an industrial area of Tuppa, Nanded, Maharashtra. Pollut Res 17:251-255

54. Kaur T, Bhardwaj R, Arora S (2016) Assessment of groundwater quality for drinking and irrigation purposes using hydrochemical studies in Malwa region, southwestern part of Punjab, India. Appl Water Sci 7:3301-3316. https://doi.org/10.1007/s1320 1-016-0476-2

55. Kebede S, Travi Y, Alemayehu T, Ayenew T (2005) Groundwater recharge, circulation and geochemical evolution in the source region of the Blue Nile River, Ethiopia. Appl Geochem 20:16581676. https://doi.org/10.1016/j.apgeochem.2005.04.016

56. Khurshid S, Zaheeruddin Shbeer MU (1997) Degradation of water quality due to heavy metal pollution in Faridabad District, Haryana, India. Pollut Res 16:41-43

57. Kowalkowski T, Zbytniewski R, Szpejna J, Buszewski B (2006) Application of chemometrics in river water classification. Water Res 40:744-752. https://doi.org/10.1016/j.watres.2005.11.042

58. Kumar DL, Sateesh K, Saxena PR, Satyanarayan E, Edukondal A (2015) Assessment of Groundwater Quality and its suitability for drinking and irrigation purpose in Maheshwaram area, Ranga Reddy District, Telegana State, India. J Environ Res Dev 9:523-529

59. Kvítek T, Žlábek P, Bystřický V et al (2009) Changes of nitrate concentrations in surface waters influenced by land use in the crystalline complex of the Czech Republic. Phys Chem Earth Parts A/B/C 34:541-551. https://doi.org/10.1016/j. pce.2008.07.003

60. Lee J, Song S (2007) Groundwater chemistry and ionic ratios in a western coastal aquifer of Buan, Korea: implication for seawater intrusion. Geosci J 11:259-270. https://doi.org/10.1007/ bf02913939

61. Li P, Wu J, Qian H (2012) Assessment of groundwater quality for irrigation purposes and identification of hydrogeochemical evolution mechanisms in Pengyang County, China. Environ Earth Sci 69(7):2211-2225. https://doi.org/10.1007/s1266 5-012-2049-5

62. Loganathan K, Ahamed A (2017) Multivariate statistical techniques for the evaluation of groundwater quality of Amaravathi River Basin: South India. Appl Water Sci 7:4633-4649. https:// doi.org/10.1007/s13201-017-0627-0

63. Majumdar D (1975) West Bengal District Gazetteer, Birbhum. State editor, Government of West Bengal, Kolkata, pp 1-79

64. Meenakumari HR, Hosmani SP (2003) Physico-chemical and biological quality of ground water in Mysore City, Karnataka. Indian J Environ Ecoplanning 71:79-82

65. Mishra AK, Arya M, Mathur R (2011) Assessment of pre-monsoon and post-monsoon groundwater quality with special reference to fluoride concentration in Narwar, Shivpuri, Madhya Pradesh, India. J Environ Res Dev 6:77-81

66. Mohamed M, Elmahdy S (2014) Natural and anthropogenic factors affecting groundwater quality in the eastern region of the United Arab Emirates. Arab J Geosci 8:7409-7423. https://doi. org/10.1007/s12517-014-1737-8

67. Mondal D, Gupta S, Reddy D, Nagabhushanam P (2014) Geochemical controls on fluoride concentrations in groundwater from alluvial aquifers of the Birbhum district, West Bengal, India. J Geochem Explor 145:190-206. https://doi. org/10.1016/j.gexplo.2014.06.005

68. Moore CV (1973) Iron in modern nutrition in health and disease. Lea and Febiger, Philadelphia, p 297

69. Nag S, Ray S (2014) Deciphering groundwater potential zones using geospatial technology: a study in Bankura block $\mathrm{i}$ and block II, Bankura District, West Bengal. Arab J Sci Eng 40:205214. https://doi.org/10.1007/s13369-014-1511-y
70. Nagarajan R, Rajmohan N, Mahendran U, Senthamilkumar $S$ (2010) Evaluation of groundwater quality and its suitability for drinking and agricultural use in Thanjavur city, Tamil Nadu, India. Environ Monit Assess 171:289-308. https://doi. org/10.1007/s10661-009-1279-9

71. Nagaraju A, Sharifi Z, Balaji E (2016) Statistical and analytical evaluation of groundwater quality of Tirupati area, Chittoor district, Andhra Pradesh, South India. J Geol Soc India 88:222-234. https://doi.org/10.1007/s12594-016-0481-y

72. Nagaraju A, Swathi A, Hudson-Edwards K (2006) Prosopis juliflora on barite mine tailings: a case study from Mangampeta region, Cuddapah district, Andhra Pradesh, India. J Am Soc Min Reclam 2006:580-591. https://doi.org/10.21000/jasmr06010 580

73. Naidu MN, Srinivas N, Prasada Roa PV (1998) Urban water quality in North Coastal Andhra Pradesh. Indian J Environ Prot 18:273-277

74. Narsimha A, Sudarshan V (2016) Contamination of fluoride in groundwater and its effect on human health: a case study in hard rock aquifers of Siddipet, Telangana State, India. Appl Water Sci 7:2501-2512. https://doi.org/10.1007/s1320 1-016-0441-0

75. Noori R, Sabahi M, Karbassi A et al (2010) Multivariate statistical analysis of surface water quality based on correlations and variations in the data set. Desalination 260:129-136. https:// doi.org/10.1016/j.desal.2010.04.053

76. Noshadi M, Ghafourian A (2016) Groundwater quality analysis using multivariate statistical techniques (case study: Fars province, Iran). Environ Monit Assess 1:2. https://doi.org/10.1007/ s10661-016-5412-2

77. Omo-Irabor O, Olobaniyi S, Oduyemi K, Akunna J (2008) Surface and groundwater water quality assessment using multivariate analytical methods: a case study of the Western Niger Delta, Nigeria. Phys Chem Earth Parts A/B/C 33:666-673. https://doi. org/10.1016/j.pce.2008.06.019

78. Panda U, Sundaray S, Rath P et al (2006) Application of factor and cluster analysis for characterization of river and estuarine water systems - a case study: Mahanadi River (India). J Hydrol 331:434-445. https://doi.org/10.1016/j.jhydrol.2006.05.029

79. Park Y, Kim N, Lee J (2015) Geochemical properties of groundwater affected by open loop geothermal heat pump systems in Korea. Geosci J 19:515-526. https://doi.org/10.1007/s1230 3-014-0059-x

80. PHED (Public Health Engineering Department) (2007) Government of West Bengal, Report. Activities \& achievements in rural drinking water supply and other areas. http://www.wbphe d.gov.in/applications/im/uploads/000643.pdf. Accessed 18 Aug 2016

81. Ramasubramanian V, Jeyaprakash R, Ruby Mallika DA, Ramasubbu R, Mariappan V (2004) Analysis of physico-chemical characteristics of ground wa-ter quality and quality index in and around Sivakasi Town. Indian J Environ Ecoplanning 8:171-176

82. Rao N, Rao P, Reddy G et al (2011) Chemical characteristics of groundwater and assessment of groundwater quality in Varaha River Basin, Visakhapatnam District, Andhra Pradesh, India. Environ Monit Assess 184:5189-5214. https://doi.org/10.1007/ s10661-011-2333-y

83. Ravikumar P, Somashekar R, Angami M (2010) Hydrochemistry and evaluation of groundwater suitability for irrigation and drinking purposes in the Markandeya River basin, Belgaum District, Karnataka State, India. Environ Monit Assess 173:459-487. https://doi.org/10.1007/s10661-010-1399-2

84. Reeves C, Suggs J (1964) Caliche of central and southern Llano Estacado, Texas. J Sediment Res 34:669-672. https://doi. org/10.1306/74d71131-2b21-11d7-8648000102c1865d 
85. Rhoades JD, Kandiah A, Mashali AM (1992) The use of saline waters for crop production. FAO Irrigation and Drainage, FAO, Rome, $\mathrm{p} 48$

86. Rusydi A (2018) Correlation between conductivity and total dissolved solid in various type of water: a review. IOP Conf Ser Earth Environ Sci 118:012019. https://doi.org/10.1088/17551315/118/1/012019

87. Salem I, Ibrahim M, Abd El Monsef M (2010) Mineralogy, geochemistry, and origin of hydrothermal manganese veins at Wadi Maliek, Southern Eastern Desert, Egypt. Arab J Geosci 5:385-406. https://doi.org/10.1007/s12517-010-0195-1

88. Shaji E, Viju Bindu J, Thambi DS (2007) High fluoride in groundwater of Palghat District, Kerala. Curr Sci 92:240-245

89. Shankar B, Balasubramanya N, Maruthesha Reddy M (2007) Impact of industrialization on groundwater quality-a case study of Peenya industrial area, Bangalore, India. Environ Monit Assess 142:263-268. https://doi.org/10.1007/s1066 1-007-9923-8

90. Sharifi Z, Safari Sinegani AA (2012) Arsenic and other irrigation water quality indicators of groundwater in an agricultural area of Qorveh plain, Kurdistan, Iran. Am Eurasian J Agric Environ Sci 12:548-555

91. Shlens J (2003) A Tutorial on principal component analysis. arXiv:1404.1100v1[cs.LG]

92. Shrestha S, Kazama F (2007) Assessment of surface water quality using multivariate statistical techniques: a case study of the Fuji river basin, Japan. Environ Model Softw 22:464-475. https ://doi.org/10.1016/j.envsoft.2006.02.001

93. Singh V, Bikundia D, Sarswat A, Mohan D (2011) Groundwater quality assessment in the village of Lutfullapur Nawada, Loni, District Ghaziabad, Uttar Pradesh, India. Environ Monit Assess 184:4473-4488. https://doi.org/10.1007/s10661-011-2279-0

94. Singh KP, Malik A, Mohan D, Singh VK, Sinha S (2006) Evaluation of groundwater quality in Northern Indo-Gangetic alluvium region. Environ Monit Assess 112:211-230

95. Singh S, Raju N, Ramakrishna C (2015) Evaluation of groundwater quality and its suitability for domestic and irrigation use in parts of the Chandauli-Varanasi Region, Uttar Pradesh, India. J Water Resource Prot 07:572-587. https://doi.org/10.4236/jwarp .2015 .77046

96. Sinha DK, Srivastava AK (1994) Water quality index for river Sai at RaeBareli for the pre-monsoon period and after the onset of monsoon. Indian J Environ Prot 15:340-345

97. Sohani D, Pande S, Srivastava VS (2001) Ground water quality at Tribal Town: Nandurbar (Maharashtra). Indian J Environ Ecoplanning 5:475-479

98. Soltan ME (1999) Evaluation of groundwater quality in Dakhla Oasis (Egyptian Western Desert). Environ Monit Assess 57:157-168

99. Suresh T, Kottureshwara NM (2009) Assessment of groundwater qualityof borewells water of Hospet Taluka Region, Karnataka, India. Rasayan J Chem 2:221-223

100. Tamma Rao G, Gurunadha Rao V, Srinivasa Rao Y, Ramesh G (2012) Study of hydrogeochemical processes of the groundwater in Ghatprabha river sub-basin, Bagalkot District, Karnataka, India. Arab J Geosci 6:2447-2459. https://doi.org/10.1007/ s12517-012-0535-4

101. Tank DK, Chandel CPS (2010) A hydrochemical elucidation of the groundwater composition under domestic and irrigated land in Jaipur City. Environ Monit Assess 166:69-77

102. Tatawat R, Chandel C (2007) A hydrochemical profile for assessing the groundwater quality of Jaipur City. Environ Monit Assess 143:337-343. https://doi.org/10.1007/s1066 1-007-9936-3
103. Tay C, Hayford E, Hodgson I (2017) Application of multivariate statistical technique for hydrogeochemical assessment of groundwater within the Lower Pra Basin, Ghana. Appl Water Sci 7:1131-1150. https://doi.org/10.1007/s13201-017-0540-6

104. Thapa R, Gupta S, Reddy D (2017) Application of geospatial modelling technique in delineation of fluoride contamination zones within Dwarka Basin, Birbhum, India. Geosci Front 8:1105-1114. https://doi.org/10.1016/j.gsf.2016.11.006

105. Thivya C, Chidambaram S, Rao M et al (2015) Assessment of fluoride contaminations in groundwater of hard rock aquifers in Madurai district, Tamil Nadu (India). Appl Water Sci 7:10111023. https://doi.org/10.1007/s13201-015-0312-0

106. U.S. Geological Survey (1966) Hydrochemical facies and ground-water flow patterns in Northern Part of Atlantic Coastal Plain. Geological Survey Professional Paper 498-A

107. Vasanthavigar M, Srinivasamoorthy K, Prasanna M (2012) Identification of groundwater contamination zones and its sources by using multivariate statistical approach in Thirumanimuthar sub-basin, Tamil Nadu, India. Environ Earth Sci 68:1783-1795. https://doi.org/10.1007/s12665-012-1868-8

108. Vázquez-Suñé E, Sánchez-Vila X, Carrera J (2004) Introductory review of specific factors influencing urban groundwater, an emerging branch of hydrogeology, with reference to Barcelona, Spain. Hydrogeol J 13:522-533. https://doi.org/10.1007/ s10040-004-0360-2

109. Viswanath N, Kumar P, Ammad K, Kumari E (2015) Ground water quality and multivariate statistical methods. Environ Process 2:347-360. https://doi.org/10.1007/s40710-015-0071-9

110. Wang S (2013) Groundwater quality and its suitability for drinking and agricultural use in the Yanqi Basin of Xinjiang Province, Northwest China. Environ Monit Assess 185:7469-7484. https ://doi.org/10.1007/s10661-013-3113-7

111. Wang Y, Jiao J (2012) Origin of groundwater salinity and hydrogeochemical processes in the confined Quaternary aquifer of the Pearl River Delta, China. J Hydrol 438-439:112-124. https ://doi.org/10.1016/j.jhydrol.2012.03.008

112. Wenning R, Erickson G (1994) Interpretation and analysis of complex environmental data using chemometric methods. TrAC Trends Anal Chem 13:446-457. https://doi. org/10.1016/0165-9936(94)85026-7

113. WHO (2011) Guideline for drinking water quality, 4th edn. World Health Organization, Geneva

114. Wongsanit J, Teartisup P, Kerdsueb P et al (2015) Contamination of nitrate in groundwater and its potential human health: a case study of lower Mae Klong river basin, Thailand. Environ Sci Pollut Res 22:11504-11512. https://doi.org/10.1007/s1135 6-015-4347-4

115. Yidana S, Banoeng-Yakubo B, Sakyi P (2012) Identifying key processes in the hydrochemistry of a basin through the combined use of factor and regression models. J Earth Syst Sci 121:491507. https://doi.org/10.1007/s12040-012-0163-0

116. Zaki S, Redwan M, Masoud A, Abdel Moneim A (2018) Chemical characteristics and assessment of groundwater quality in Halayieb area, southeastern part of the Eastern Desert, Egypt. Geosci J 23:149-164. https://doi.org/10.1007/s12303-018-0020-5

117. Zhang Q, Li Z, Zeng G et al (2008) Assessment of surface water quality using multivariate statistical techniques in red soil hilly region: a case study of Xiangjiang watershed, China. Environ Monit Assess 152:123-131. https://doi.org/10.1007/s1066 1-008-0301-y

Publisher's Note Springer Nature remains neutral with regard to jurisdictional claims in published maps and institutional affiliations. 